\title{
Application of human amniotic epithelial cells in regenerative medicine: a systematic review
}

\author{
Qiuwan Zhang and Dongmei Lai (1)
}

\begin{abstract}
Human amniotic epithelial cells (hAECs) derived from placental tissues have gained considerable attention in the field of regenerative medicine. hAECs possess embryonic stem cell-like proliferation and differentiation capabilities, and adult stem cell-like immunomodulatory properties. Compared with other types of stem cell, hAECs have special advantages, including easy isolation, plentiful numbers, the obviation of ethical debates, and non-immunogenic and non-tumorigenic properties. During the past two decades, the therapeutic potential of hAECs for treatment of various diseases has been extensively investigated. Accumulating evidence has demonstrated that hAEC transplantation helps to repair and rebuild the function of damaged tissues and organs by different molecular mechanisms. This systematic review focused on summarizing the biological characteristics of hAECs, therapeutic applications, and recent advances in treating various tissue injuries and disorders. Relevant studies published in English from 2000 to 2020 describing the role of hAECs in diseases and phenotypes were comprehensively sought out using PubMed, MEDLINE, and Google Scholar. According to the research content, we described the major hAEC characteristics, including induced differentiation plasticity, homing and differentiation, paracrine function, and immunomodulatory properties. We also summarized the current status of clinical research and discussed the prospects of hAEC-based transplantation therapies. In this review, we provide a comprehensive understanding of the therapeutic potential of hAECs, including their use for cell replacement therapy as well as secreted cytokine and exosome biotherapy. Moreover, we showed that the powerful immune-regulatory function of hAECs reveals even more possibilities for their application in the treatment of immune-related diseases. In the future, establishing the optimal culture procedure, achieving precise and accurate treatment, and enhancing the therapeutic potential by utilizing appropriate preconditioning and/or biomaterials would be new challenges for further investigation.
\end{abstract}

Keywords: Human amniotic/amnion epithelial cells, Cell transplantation, Differentiation, Paracrine properties, Immunomodulation, Regenerative medicine

\footnotetext{
* Correspondence: laidongmei@hotmail.com

The International Peace Maternity and Child Health Hospital, School of

Medicine, Shanghai Jiao Tong University; Shanghai Key Laboratory of Embryo

Original Diseases; Shanghai Municipal Key Clinical Speciality, 145,

Guang-Yuan Road, Shanghai 200030, People's Republic of China
}

(C) The Author(s). 2020 Open Access This article is licensed under a Creative Commons Attribution 4.0 International License, which permits use, sharing, adaptation, distribution and reproduction in any medium or format, as long as you give appropriate credit to the original author(s) and the source, provide a link to the Creative Commons licence, and indicate if changes were made. The images or other third party material in this article are included in the article's Creative Commons licence, unless indicated otherwise in a credit line to the material. If material is not included in the article's Creative Commons licence and your intended use is not permitted by statutory regulation or exceeds the permitted use, you will need to obtain permission directly from the copyright holder. To view a copy of this licence, visit http://creativecommons.org/licenses/by/4.0/ The Creative Commons Public Domain Dedication waiver (http://creativecommons.org/publicdomain/zero/1.0/) applies to the data made available in this article, unless otherwise stated in a credit line to the data. 


\section{Background}

Human amniotic/amnion epithelial cells (hAECs) are derived from the innermost layer of the term placenta closest to the fetus, and they have been shown to have the potential to be seed cells for allogeneic cell therapies. Over the past 20 years, interest has been growing regarding the utility of hAECs in regenerative medicine due to their proliferative capacity, multilineage differentiation potential, ease of access, and safety. Advances in stem cell-based approaches have revealed that hAECs are perinatal stem cells that possess embryonic stem celllike properties and the ability to be induced to differentiate. As promising seed stem cell, hAECs have been widely used to treat various diseases through transplantation therapy. Evidence supported by animal studies has revealed that hAECs show therapeutic potential for treatment of many diseases, including neurological disorders [1-4], lung injury [5, 6], liver injury [7], diabetes [8], acute kidney failure [9], cardiovascular diseases [10], wound healing [11], healing of stage III pressure ulcers [12], intrauterine adhesion [13], and premature ovarian failure (POF) [14]. Although hAECs have exhibited good therapeutic efficacy, they possess differences in differentiation potential, secretory function, and immunomodulatory activity under different conditions, producing specific effects depending on their application. In this review, we mainly examined the literature about the therapeutic potential of hAECs and summarized the different repair mechanisms in injured tissues and disorders; we also discussed the induced differentiation plasticity, homing and differentiation, paracrine function, and immunomodulatory capacity of hAECs. Finally, we described the current research strategies and proposed new prospects for hAEC-based clinical applications in the future.

\section{Methods}

Comprehensive literature searches using PubMed, MEDLINE, or Google Scholar were performed to identify articles for review written in English focusing on the biology of hAECs and the role of hAECs in injured tissues, diseases, and regenerative medicine.

\section{Biological characteristics of hAECs}

hAECs are obtained from the amniotic membrane of term placentas, which are discarded after birth. Thus, hAECs are readily available, require no invasive procedures for harvesting, and avoid relevant ethical issues. Isolated hAECs express surface markers of embryonic stem cells such as stage-specific embryonic antigen-3 and 4 (SSEA-3 and SSEA-4), octamer-binding transcription factor-4 (OCT-4), and tumor rejection antigen1-60 and 1-80 (TRA1-60 and TRA1-80) [15]. Although hAECs possess stem cell-like characteristics, they do not exhibit unlimited proliferation due to the lack of telomerase activity and no risk of tumorigenesis in vivo [16]. Moreover, hAECs have tri-mesodermal lineage differentiation potential; they can produce osteogenic, adipogenic, and chondrogenic lineages under appropriate culture conditions [17]. Notably, hAECs have low expression levels of human leukocyte antigens (including HLA-A, HLA-B, and HLA-C and HLA-DR), which are key antigens involved in recipient rejection [1, 18]. A study confirmed that intravenous administration of hAECs did not result in hemolysis, allergic reactions, toxicity, or tumor formation, which demonstrated that hAECs were systematically safe [19]. Thus, hAECs are considered a promising source of stem cells for regenerative medicine.

To safely and effectively use hAECs to repair the function of injured tissues and treat diseases, it is essential that they are of high quality. Currently, the trypsin/EDTA technique is the most efficient for obtaining viable hAECs for subsequent culture [20, 21]. The key aspects involved in the isolation of hAECs with high yield, viability, and purity have been previously summarized [22]. Meanwhile, standard manufacturing and cryopreservation process were established that resulted in the isolation of highly purified hAECs with reproducible and high viability in accordance with current good manufacturing procedure (GMP) requirements [23]. In addition, a study found that epidermal growth factor (EGF) was a strong mitogen that promoted the proliferation of hAECs by regulating the cell cycle rather than inducing differentiation in the process of culture in vitro [24]. Although primary hAECs strongly expressed stemness-related genes for OCT-4, Sox-2, and Nanog, these gene expression levels gradually declined with an increase in passage number [25]. Study revealed that cultured hAECs underwent epithelial to mesenchymal transition (EMT) through the autocrine production of TGF-beta (TGF- $\beta$ ) [26]. Moreover, TNF-alpha (TNF- $\alpha$ ) and matrix metalloproteinase (MMP) could induce EMT of hAECs [27]. Therefore, researchers have tried to explore different culture methods to maintain stemness and avoid EMT occurrence. A study found that hAECs were cultured in substitute serum medium (SSM) in which fetal calf serum (FCS) was replaced by knockout serum replacement (SR), contributing to maintain stem cell characteristics for up to 4 passages [28]. Furthermore, xenobiotic-free medium was used for the culture of hAECs to eliminate the effects of growth factors [29]. Meanwhile, a serum-free protocol established for hAEC isolation and culture resulted in better cell growth than that achieved by a traditional culture system with serum [19], which made the clinical applications of hAECs more feasible. 
Although the biological characteristics of hAECs could be affected by the culture conditions and number of passages, they can be sufficiently expanded under certain culture conditions and maintain reproducible biological characteristics. Therefore, further understanding of the biological characteristics of hAECs and improvement of the isolation and culture techniques are important for applying hAECs in regenerative medicine.

\section{Induced differentiation plasticity of hAECs in vitro}

One study indicated that hAECs were more efficiently reprogrammed to assume a state of induced pluripotency than adult fibroblasts [30]. An increasing number of studies have found that hAECs display an extremely high level of differentiation plasticity in vitro following chemical induction, biological treatment, gene transfection, or coculture with other types of cells (Table 1).

A series of studies reported that hAECs were successfully induced to differentiate into hepatocyte-like cells through a combined approach using dexamethasone, hepatocyte growth factor (HGF), insulin-like growth factor (IGF), and other cytokines [31]; extracellular matrix proteins together with a mixture of growth factors, cytokines, and hormones or cocultured with muse hepatocytes [32]; a specific hepatic differentiation protocol [33]; and four-step hepatic differentiation [34]. In addition, hAECs could respond to proangiogenic signals, form capillary-like structures, and differentiate into hepatic sinusoidal endothelial cells (HSECs) in vivo [35].

With regard to pancreatic cells, hAECs were induced to form three-dimensional (3D) spheroids and differentiate into insulin-producing cells by culturing them on an extracellular matrix [36]. When hAECs were treated with activin A or nicotinamide combined with the transcription factor pancreatic and duodenal homeobox-1 (PDX1), they differentiated into pancreatic lineage cells [37]. Furthermore, hAECs differentiated into islet-like cells expressing endocrine-related genes, including PDX1, insulin, and glucagon, as a result of the addition of nicotinamide plus betacellulin; importantly, the differentiated islet-like cells secreted high levels of insulin in response to high glucose exposure $[38,39]$. In addition, the potential for the differentiation of hAECs into pancreatic cells triggered by overexpressing PDX1 could be strengthened with a mix of EGF and poly-L-ornithine in the culture environment [40]. A study showed that hAECs cocultured with submandibular gland acinar cells in a double-chamber system differentiated into acinar cells [41]. When hAECs were treated with nicotinamide and N2 supplement, they differentiated into insulin secreting cells (ISCs) expressing PDX1 and beta2 microglobulin, meaning that they show potential for application to cell therapy of type I diabetes [42].
The fluid from specific tissues and organs could also affect the process of hAEC differentiation. It was confirmed that hAECs cultured with medium containing 5\% human follicular fluid expressed the germ cell-specific markers GDF9 and DAZL [43], and formed a folliclelike structure [44]. By using serum substitute supplement (SSS) medium, hAECs were induced to differentiate into germ cells expressing DAZL, VASA, GDF9, and ZP3 [45].

The ability of hAECs to differentiate into corneal epithelial-like cells has been confirmed in many studies. For example, hAECs were induced to differentiate into corneal epithelial-like cells when they were cocultured with human corneal epithelial cells (hCECs) [46] and seeded onto rabbit corneal stroma [47] or by using culture media collected from spontaneously immortalized human corneal epithelial cells (S-ihCECs) to replicate the corneal epithelial microenvironment [48]. These methods may be suitable for the reconstruction of the corneal epithelium. Additionally, hAECs were able to differentiate into conjunctival epithelium-like cells with partial physiological function upon culture with induced-denuded conjunctival matrix and conjunctival homogenate [49].

The capability of hAECs to differentiate into neural cells was affected by factors including serum, noggin, basic fibroblast growth factor (bFGF), and retinoic acid [50]. A recent study showed that hAECs were induced to undergo neuronal differentiation by treatment with rosmarinic acid [51]. hAECs differentiated into cortical progenitor lineage cells and showed a cortical neuron phenotype when treated with growth factors and small molecules [52]. Additionally, hAECs were induced to differentiate into Schwann-like cells (SCs) that exhibited the morphological, phenotypic, and functional characteristics of SCs when they were treated according to a coculture approach [53].

Osteogenic differentiation of hAECs was induced by the upregulation of Runx2, osterix, alkaline phosphatase (ALP), collagen I, and osteopontin (OPN) in vitro [54]. hAECs treated with either bone morphogenetic protein (BMP)- 7 or TGF- $\beta 1$ expressed cartilage markers, including aggrecan, Sox-9, CEP-68, and type II and X collagens [55]. Interestingly, the osteogenic differentiation of hAECs was also induced by mechanical stretching [56], which means that changing the physical conditions may be a new approach to affect the process of hAEC differentiation.

Additionally, hAECs could form 3D structures and express the cystic fibrosis transmembrane conductance regulator (CFTR) by adding small airway growth medium (SAGM) [57]. When treated with activin A and BMP-4, hAECs were able to express cardiac-specific genes, including Nkx2.5 and alpha-actinin, indicating 
Table 1 The induced differentiation of hAECs in vitro

\begin{tabular}{|c|c|c|c|c|}
\hline Organ/focuses & Cell types & Phenotypes & Inducing conditions & References \\
\hline \multirow[t]{5}{*}{ Liver } & Hepatocyte-like cells & $\begin{array}{l}\text { Expressing hepatocyte-like cell } \\
\text { functional genes: albumin, CYP1A1, } \\
\text { CYP1A2, c-met, and transcription } \\
\text { factors: HNF3, HNF4, C/EBPa, and } \\
\text { HNF1 }\end{array}$ & $\begin{array}{l}\text { Using a combined approach } \\
\text { of dexamethasone, HGF, IGF, } \\
\text { and other cytokines }\end{array}$ & [31] \\
\hline & Hepatocyte-like cells & $\begin{array}{l}\text { Expressing hepatic related } \\
\text { genes: albumin, A1AT, CYP3A4, } \\
3 \mathrm{~A} 7,1 \mathrm{~A} 2,2 \mathrm{~B} 6 \text {, and the } \\
\text { asialoglycoprotein receptor } 1 \\
\text { (ASGPR1) }\end{array}$ & $\begin{array}{l}\text { Using extracellular matrix } \\
\text { substrates; cocultured with } \\
\text { mouse hepatocytes }\end{array}$ & [32] \\
\hline & Hepatic differentiation & $\begin{array}{l}\text { Displayed a similar hepatic } \\
\text { morphology; expressing specific } \\
\text { hepatic genes: albumin, CYP7A1, } \\
\text { and CYP3A4 }\end{array}$ & $\begin{array}{l}\text { Using a specific hepatic } \\
\text { differentiation protocol }\end{array}$ & [33] \\
\hline & Hepatic differentiation & $\begin{array}{l}\text { The formation of bile canaliculi; } \\
\text { secreting albumin; uptaking low- } \\
\text { density lipoprotein and showing } \\
\text { inducible CYP3A4 and CYP2C9 } \\
\text { enzymatic activities }\end{array}$ & $\begin{array}{l}\text { Using four-step hepatic } \\
\text { differentiation protocol }\end{array}$ & [34] \\
\hline & Hepatic sinusoidal endothelial cells & $\begin{array}{l}\text { Forming capillary-like structure } \\
\text { in vitro and differentiate into } \\
\text { HSECs in vivo }\end{array}$ & $\begin{array}{l}\text { Under proangiogenic } \\
\text { conditions }\end{array}$ & [35] \\
\hline \multirow[t]{7}{*}{ Pancreas } & Insulin-producing cells & $\begin{array}{l}\text { The formation of three-dimensional } \\
\text { (3D) spheroids; producing pancreatic } \\
\text { endocrine hormones; releasing } \\
\text { C-peptide under hyperglycemic } \\
\text { condition }\end{array}$ & $\begin{array}{l}\text { Culturing on extracellular } \\
\text { matrix }\end{array}$ & [36] \\
\hline & Pancreatic lineage cells & $\begin{array}{l}\text { Expressing pancreatic endoderm } \\
\text { and progenitor genes: NKX6.1, } \\
\text { NeuroD1, and pancreatic lineage } \\
\text { genes: PDX1, SOX17, RFX6 }\end{array}$ & $\begin{array}{l}\text { Combination of transcription } \\
\text { factor PDX } 1 \text { with activin A or } \\
\text { nicotinamide }\end{array}$ & [37] \\
\hline & Islet-like cells & $\begin{array}{l}\text { Expressing the endocrine- } \\
\text { related genes: PDX1, ngn3, } \\
\text { insulin, and glucagon; secreting } \\
\text { insulin in response to high } \\
\text { glucose exposure }\end{array}$ & $\begin{array}{l}\text { Using DMEM with different } \\
\text { supplements and suspension } \\
\text { culture }\end{array}$ & [38] \\
\hline & Islet-like cell clusters & $\begin{array}{l}\text { Expressing pancreatic } \\
\text { development-related genes: } \\
\text { PDX1, NKX6-1, NEUROG3, PAX6, } \\
\text { INS, and GCG; insulin positive } \\
\text { and sensitive to glucose }\end{array}$ & $\begin{array}{l}\text { Adding nicotinamide plus } \\
\text { betacellulin }\end{array}$ & [39] \\
\hline & Pancreatic cells & $\begin{array}{l}\text { Expressing pancreatic } \\
\text { differentiation related genes: } \\
\text { NKX6.1, SOX17, RFX6, NEUROD1, } \\
\text { and PAX4 }\end{array}$ & $\begin{array}{l}\text { Inducing endogenous PDX1 } \\
\text { expression, EGF, and poly-L- } \\
\text { ornithine }\end{array}$ & {$[40]$} \\
\hline & Acinar cells & Expressing a-amylase and mucins & $\begin{array}{l}\text { Cocultured with submandibular } \\
\text { gland acinar cells using a double- } \\
\text { chamber system }\end{array}$ & [41] \\
\hline & Insulin secreting cells & $\begin{array}{l}\text { Expressing PDX1 and beta2 } \\
\text { microglobulin; secreting insulin }\end{array}$ & $\begin{array}{l}\text { Treated with nicotinamide } \\
\text { and N2 supplement }\end{array}$ & [42] \\
\hline \multirow[t]{3}{*}{ Ovary } & Germ cell-like cells & $\begin{array}{l}\text { Expressing germ cell-specific } \\
\text { genes: GDF9, DAZL, and SCP3; } \\
\text { producing estradiol }\end{array}$ & $\begin{array}{l}\text { Medium supplemented with } \\
5 \% \text { human follicular fluid }\end{array}$ & [43] \\
\hline & Follicle-like structure & $\begin{array}{l}\text { Expressing germ cell-specific } \\
\text { genes DAZL and GDF9; } \\
\text { secreting estradiol }\end{array}$ & $\begin{array}{l}\text { Medium supplemented with } \\
5 \% \text { human follicular fluid }\end{array}$ & [44] \\
\hline & Germ cell-like cells (diploid cells) & Expressing germ cell-specific & $\begin{array}{l}\text { Cultured in medium containing } \\
\text { serum substitute supplement (SSS) }\end{array}$ & [45] \\
\hline
\end{tabular}


Table 1 The induced differentiation of hAECs in vitro (Continued)

\begin{tabular}{|c|c|c|c|c|}
\hline Organ/focuses & Cell types & Phenotypes & Inducing conditions & References \\
\hline \multirow[t]{4}{*}{ Eyes } & Corneal epithelial-like cells & $\begin{array}{l}\text { Showing a similar morphology } \\
\text { to hCECs; expressing CK3/12, } \\
\text { CK14, CK19, and P63 }\end{array}$ & $\begin{array}{l}\text { Cultured with human corneal } \\
\text { epithelial cells (hCECs) in a } \\
\text { Transwell coculture system }\end{array}$ & [46] \\
\hline & Corneal epithelial-like cells & Expressing CK3/12 & $\begin{array}{l}\text { Seeded onto rabbit corneal } \\
\text { stroma }\end{array}$ & {$[47]$} \\
\hline & Corneal epithelial-like cells & Expressing CK3/12 & $\begin{array}{l}\text { Adding the conditioned medium } \\
\text { of spontaneously immortalized } \\
\text { human corneal epithelial cells } \\
\text { (S-ihCECs) }\end{array}$ & [48] \\
\hline & Conjunctival epithelium-like cells & $\begin{array}{l}\text { Showed conjunctival epithelium } \\
\text { phenotype; producing mu5ac }\end{array}$ & $\begin{array}{l}\text { Cultured with induced- } \\
\text { denuded conjunctival matrix } \\
\text { and conjunctival homogenate }\end{array}$ & [49] \\
\hline \multirow[t]{4}{*}{ Nervous system } & Neuronal differentiation & $\begin{array}{l}\text { Expressing neural cell markers } \\
\text { NSE and NeuN }\end{array}$ & $\begin{array}{l}\text { Adding noggin, bFGF, and } \\
\text { retinoic acid }\end{array}$ & [50] \\
\hline & Neuronal differentiation & $\begin{array}{l}\text { Upregulation of transcription factors } \\
\text { involving in neuronal differentiation }\end{array}$ & Treated with rosmarinic acid & [51] \\
\hline & Cortical progenitors & $\begin{array}{l}\text { Expressing cortical neuron- } \\
\text { specific proteins: TBR2, OTX2, } \\
\text { NeuN, and } \beta \text {-III-tubulin }\end{array}$ & $\begin{array}{l}\text { Adding growth factors and } \\
\text { small molecules }\end{array}$ & [52] \\
\hline & Schwann-like cells & $\begin{array}{l}\text { Exhibiting a typical bipolar or tripolar } \\
\text { morphology; expressing S-100; } \\
\text { increasing the expressions of BDNF } \\
\text { and GDNF }\end{array}$ & $\begin{array}{l}\text { Cocultured with Schwann } \\
\text { cells (SCs) }\end{array}$ & [53] \\
\hline \multirow[t]{3}{*}{ Bone } & Osteogenic differentiation & $\begin{array}{l}\text { Increasing cellular ALP activity } \\
\text { and extracellular mineralization; } \\
\text { expressing Runx2, Osterix, ALP, } \\
\text { collagen I, and OPN }\end{array}$ & $\begin{array}{l}\text { Cultured with classic osteogenic } \\
\text { medium }\end{array}$ & [54] \\
\hline & Cartilage differentiation & $\begin{array}{l}\text { Expressing cartilage markers: } \\
\text { aggrecan, Sox9, CEP-68, and type } \\
\| \text { and } X \text { collagens; promoting } \\
\text { matrix synthesis }\end{array}$ & Treated with BMP-7 or TGF- $\beta 1$ & [55] \\
\hline & Osteoblasts & Upregulating Runx2, ALP, and OPN & Mechanical stretch & [56] \\
\hline Respiratory & Polarized airway-like cells & $\begin{array}{l}\text { Forming 3D structures; expressing } \\
\text { CFTR and possessing functional } \\
\text { iodide/chloride }\left(\left(^{-} / \mathrm{Cl}^{-}\right) \text {ion channels }\right.\end{array}$ & $\begin{array}{l}\text { Cultured with small airway } \\
\text { growth medium (SAGM) }\end{array}$ & [57] \\
\hline Heart & Cardiomyocyte-like cells & $\begin{array}{l}\text { Expressing cardiac-specific genes } \\
\mathrm{Nkx2.5} \text { and alpha-actinin }\end{array}$ & $\begin{array}{l}\text { Treated with activin } A \text { and } \\
\text { BMP-4 }\end{array}$ & [58] \\
\hline Skin & Epidermal cells & $\begin{array}{l}\text { The presence of desmosomes; } \\
\text { expressing CK18 and CK14 }\end{array}$ & Cultured in air-liquid interface & [59] \\
\hline
\end{tabular}

that hAECs have the potential to differentiate into cardiomyocytes [58]. In addition, the air-liquid interface could stimulate the early differentiation of hAECs into epidermal cells, which indicates their potential use for skin regeneration [59].

Taken together, these studies indicate that hAECs have strong potential to be induced to differentiate via changes in culture conditions and methods. Inducing the differentiation of hAECs toward a desired phenotype in vitro before injection or transplantation will be an effective method for replacing damaged cells for tissue regeneration.

\section{Homing and differentiation of hAECs in vivo}

In addition to culture conditions, the differentiation potential of hAECs largely depends on the specific organizational microenvironment in vivo following transplantation. Grafted hAECs could migrate to injured tissue and further differentiate into the appropriate cell type under different conditions. Extensive animal studies have confirmed the capacity of hAECs to differentiate into essential and specialized cell types, which participate in the functional recovery of damaged tissues (Table 2).

Generally, the initial presence of injury or damage causes early cell death and loss of functional cells, and then a series of secondary reactions occur, including hypoxia, inflammation, ischemia, and dysfunction. Study reported that hAECs not only expressed specific markers of nerve cells, but also migrated along nerve fibers in the corpus callosum [69]. A series of studies demonstrated that hAECs exerted neuroprotective effects, possibly in 
Table 2 Homing and differentiation of hAECs in vivo

\begin{tabular}{|c|c|c|c|c|c|}
\hline Diseases/focuses & $\begin{array}{l}\text { Transplantation } \\
\text { method/dose }\end{array}$ & Species & Outcome & Repair mechanism & References \\
\hline Parkinson's disease & $\begin{array}{l}\text { Injection of striatum } \\
\left(4 \times 10^{4} \text { cells }\right)\end{array}$ & Rats & $\begin{array}{l}\text { Ameliorating of apomorphine } \\
\text {-induced rotational asymmetry }\end{array}$ & $\begin{array}{l}\text { Differentiating into TH- } \\
\text { immunoreactive cells }\end{array}$ & [60] \\
\hline $\begin{array}{l}\text { Ischemic brain } \\
\text { injury }\end{array}$ & $\begin{array}{l}\text { Injection of dorsolateral } \\
\text { striatum }\left(8 \times 10^{5} \text { cells }\right)\end{array}$ & Rats & $\begin{array}{l}\text { Ameliorating behavioral } \\
\text { dysfunction; reducing infarct } \\
\text { volume }\end{array}$ & $\begin{array}{l}\text { Expressing neuronal progenitor } \\
\text { marker (Nestin), neuronal marker } \\
\text { (MAP 2), astrocyte marker (GFAP) }\end{array}$ & [61] \\
\hline Alzheimer's disease & $\begin{array}{l}\text { Intracerebroventricular } \\
\text { injection }\left(1.2 \times 10^{5} \text { cells }\right)\end{array}$ & Mice & $\begin{array}{l}\text { Improving the spatial memory; } \\
\text { increasing acetylcholine } \\
\text { concentration and the number of } \\
\text { hippocampal cholinergic neurites }\end{array}$ & $\begin{array}{l}\text { Expressing stem cell-specific } \\
\text { markers OCT-4 and Nanog }\end{array}$ & [62] \\
\hline Chronic liver failure & $\begin{array}{l}\text { Intrasplenical injection } \\
\left(2 \times 10^{6} \text { cells }\right)\end{array}$ & Mice & $\begin{array}{l}\text { Liver was larger in size, softer, } \\
\text { and less nodular; increasing } \\
\text { serum albumin level }\end{array}$ & $\begin{array}{l}\text { Differentiating into functional } \\
\text { hepatocytes positive for albumin }\end{array}$ & [34] \\
\hline Lung injury & $\begin{array}{l}\text { Fetal jugular vein } \\
\left(3 \times 10^{6} \text { cells }\right)\end{array}$ & Sheep & $\begin{array}{l}\text { Reducing ventilation-induced } \\
\text { preterm lung injury, including } \\
\text { less collagen, elastin, fibrosis, } \\
\text { normalized secondary-septal } \\
\text { crests }\end{array}$ & $\begin{array}{l}\text { Differentiating into type I } \\
\text { and II alveolar cells }\end{array}$ & [63] \\
\hline $\begin{array}{l}\text { Premature ovarian } \\
\text { failure }\end{array}$ & $\begin{array}{l}\text { Intravenously injection } \\
\left(2 \times 10^{6} \text { cells }\right)\end{array}$ & Mice & $\begin{array}{l}\text { Promoting folliculogenesis; } \\
\text { repairing ovarian function }\end{array}$ & $\begin{array}{l}\text { Differentiating into granulosa } \\
\text { cells expressing follicle- } \\
\text { stimulating hormone receptor } \\
\text { (FSHR) }\end{array}$ & [64] \\
\hline $\begin{array}{l}\text { Myocardial } \\
\text { infarction }\end{array}$ & $\begin{array}{l}\text { Injection of the infarcted } \\
\text { myocardium }\left(1 \times 10^{6} \text { cells }\right)\end{array}$ & Rats & $\begin{array}{l}\text { Decreasing infarct size; } \\
\text { improving cardiac function }\end{array}$ & $\begin{array}{l}\text { Differentiating into } \\
\text { cardiomyocyte-like cells } \\
\text { expressing myocardium- } \\
\text { specific marker myosin heavy } \\
\text { chain }\end{array}$ & [65] \\
\hline Gland injury & $\begin{array}{l}\text { Intra-glandular injection } \\
\left(1 \times 10^{6} \text { cells }\right)\end{array}$ & Mice & $\begin{array}{l}\text { Restoring the morphology } \\
\text { and function of salivary gland }\end{array}$ & $\begin{array}{l}\text { Differentiating into acinar- } \\
\text { like cells }\end{array}$ & [66] \\
\hline Inner ear injury & $\begin{array}{l}\text { Injection of cochlea } \\
\left(1 \times 10^{5} \text { cells }\right)\end{array}$ & $\begin{array}{l}\text { Hartley guinea } \\
\text { pigs }\end{array}$ & $\begin{array}{l}\text { Cooperation in the regional } \\
\text { potassium ion recycling }\end{array}$ & $\begin{array}{l}\text { Expressing cochlear fibrocyte } \\
\text { markers connexin } 26 \text { and Na- } \\
\text { K-adenosine triphosphatase }\end{array}$ & [67] \\
\hline $\begin{array}{l}\text { Achilles tendon } \\
\text { injury }\end{array}$ & $\begin{array}{l}\text { In situ injection } \\
\left(10 \times 10^{6} \text { cells }\right)\end{array}$ & Sheep & $\begin{array}{l}\text { Improving tendon } \\
\text { microarchitecture and blood } \\
\text { vessel remodeling; contributing } \\
\text { to tendon regeneration }\end{array}$ & $\begin{array}{l}\text { Differentiating into tenocytes } \\
\text { expressing collagen I }\end{array}$ & [68] \\
\hline
\end{tabular}

relation to neuronal differentiation. In a Parkinson's disease (PD) model, hAECs migrated to and survived in the injured striatum, and partially ameliorated apomorphineinduced rotational asymmetry through differentiating into $\mathrm{TH}$-immunoreactive cells [60]. Another study found that grafted hAECs migrated to the injured brain area via a CXC chemokine receptor type 4 (CXCR4)-dependent mechanism in ischemic stroke [70], and chemokines released by damaged tissues were a key mediator of transplanted stem cell tracking to the site of injury [71]. In ischemic brain injury, grafted hAECs migrated into the ischemic area and expressed the neuronal specific marker (MAP 2) and neuronal progenitor marker (Nestin), and they significantly ameliorated behavioral dysfunction and reduced infarct volume [61]. In transgenic mice with Alzheimer's disease (AD), transplanted hAECs survived for at least 8 weeks, and they were shown to migrate to the third ventricle without immune rejection and to express the stem cell markers OCT-4 and Nanog [62]. In thioacetamide-induced chronic liver failure, engrafted hAECs migrated into the liver and differentiated into functional hepatocyte-like cells, improved the state of the liver following chronic injury, and produced a high level of serum albumin [34]. In addition, transplanted hAECs differentiated into type I and II alveolar cells and mitigated ventilation-induced preterm lung injury [63]. In chemotherapy-induced POF, grafted hAECs were shown to migrate to the injured ovaries and differentiate into granulosa cells to restore folliculogenesis and ovarian function [64]. In myocardial infarction, hAECs improved cardiac function following transplantation by differentiating into cardiomyocyte-like cells [65]. In gland injury induced by radiation, hAECs in the recipient glands differentiated into acinar-like cells, resulting in morphological and functional restoration of the salivary gland [66]. Additionally, transplanted hAECs could express connexin 26 and $\mathrm{Na}$-K-adenosine triphosphatase in the inner ear [67]. In Achilles tendon injury, hAECs remained 
viable within the host tendons and established an active dialogue with endogenous progenitor cells, and the differentiated hAECs displayed a tenocyte-like phenotype and contributed to the recovery of the function of Achilles tendon [68].

Although numerous studies have demonstrated that hAECs can migrate and differentiate into the desired type of cells to replace damaged cells, only a few studies have reported the long-term functional integration of engrafted hAECs in target organs. The limited homing efficiency and the lack of long-term cell tracking approaches could be major reasons for the lack of functional research on differentiated cells. In addition to the efficacy of engraftment, several additional factors for hAEC therapy need to be considered, including the number of administered cells, the route of infusion, and the biodistribution of cells post-transplantation. Although tail vein injection is the most widely used transplantation method to deliver cells into a host, most engrafted cells are trapped in the lungs rather than the target organs. For example, splenic injection was a more efficient route of administration of hAECs for targeting the liver than tail vein infusion [72, 73]. Therefore, selecting an appropriate transplantation route is vital for cell survival, differentiation of grafted cells, and the recovery of function.

Therefore, transplanted hAECs can be recruited to damaged tissues and exert differentiation plasticity in vivo based on the specific types of cells needed for replacement therapy to treat many diseases.

\section{Paracrine potential of hAECs}

Migration of grafted hAECs to injured tissues and replacement of damaged cells are thought to be the mechanisms behind the alleviation of acute and chronic injury; however, there are several obstacles to cell transplantation, such as poor survival and limited restoration ability. Currently, accumulating evidence has demonstrated that hAECs can provide a beneficial microenvironment for cell survival and activate endogenous mechanisms of tissue regeneration by secreting bioactive cytokines and microvesicles. This is supported by evidence that the injection of the conditioned media of hAECs (hAEC-CM) could achieve a positive outcome similar to that of cell transplantation, representing an acceptable alternative for stem cell-free biotherapy. As early as 2000, a study showed that hAECs could synthesize and release brain-derived neurotrophic factor (BDNF), neurotrophin-3 (NT-3), and nerve growth factor (NGF), which play important roles in the early stages of neural development in the embryo as well as the neuroprotective effect $[74,75]$. Moreover, study also showed that hAECs secreted considerable amounts of proangiogenic, anti-fibrotic, and anti-inflammatory factors, including basic fibroblast growth factor (bFGF), vascular endothelial growth factor (VEGF), angiogenin (AGN), and insulin-like growth factor (IGF) [76]. The therapeutic function of these bioactive secretory factors in various disease models has been studied and confirmed (Table 3).

For example, hAECs enhanced the survival of dopamine (DA) neurons by producing biologically activated neurotrophins, such as BDNF and NT-3, and they counteracted the loss of DA neurons in PD model mice [60,77]. In corneal injury, hAEC-CM injection promoted corneal wound healing by reducing the infiltration of inflammatory cells [78] and reducing corneal neovascularization [79]. hAEC$\mathrm{CM}$ injection protected ovaries against chemotherapyinduced damage, enhanced the ovarian microenvironment, and promoted ovarian vessel formation [80]. Further study found that hAEC-secreting TGF- $\beta 1$ played important roles in protecting granulosa cells against apoptosis [81]. On the other hand, study has shown that hAECs suppressed collagen production in human hepatic stellate cells through the paracrine pathway [89], and some important soluble factors such as MMP-2 and MMP-9 secreted by hAECs played vital roles in antifibrosis and promoting extracellular matrix (ECM) remodeling, especially in liver injury and fibrosis models $[7,82]$. In a diet-induced murine non-alcoholic steatohepatitis (NASH) model, administration of hAEC-CM reduced liver fibrosis and hepatic inflammation, supporting the antifibrotic properties of hAEC-CM [83]. Although hAECs have been reported to secrete angiogenic factors, including EGF, VEGF, AGN, and platelet-derived growth factor B (PDGFB), there have been some contradictory reports on their angiogenic effects to date. A study revealed that significantly different protective effects were exerted by term and preterm hAECs in vivo [90], which was related to the differences in the angiogenic ability of hAECs isolated from different gestational stages [91]. In addition, the impact of hAECs on angiogenesis could be influenced by the presence of inflammation in injured tissue [91]. Study found that hAECs under hypoxic condition could secrete the high levels of the human-origin proangiogenic cytokines, contributing to myocardial tissue regeneration [10]. Thus, the impact of microenvironmental biological cues on the paracrine function of transplanted hAECs should be considered to identify the optimal times for cell administration.

In addition, microvesicles or exosomes, as essential components of the hAEC paracrine pathway, have attracted much attention. Exosomes are small secretory vesicles that are involved in intercellular communication via the transport of bioactive cargo, including proteins, mRNA, microRNAs (miRNAs), and organelles [92]. Importantly, study has demonstrated that exosomes released by stem cells can effectively transport proteins, mRNAs, and miRNAs to exert a variety of effects on target tissues [93]. It has been shown 
Table 3 Paracrine function of hAECs in different diseases

\begin{tabular}{|c|c|c|c|c|c|}
\hline Diseases/focuses & Injection method & Species & Outcome & Repair mechanism & References \\
\hline Parkinson's disease & $\begin{array}{l}\text { Injection of tegmentum of the } \\
\text { midbrain }\end{array}$ & Rats & $\begin{array}{l}\text { Enhancing the survival of DA; } \\
\text { protecting the morphological } \\
\text { integrity of TH-positive neurons } \\
\text { against toxic insult }\end{array}$ & $\begin{array}{l}\text { hAEC-CM (neurotrophins } \\
\text { such as BDNF and NT-3) }\end{array}$ & [77] \\
\hline Corneal alkali injury & $\begin{array}{l}\text { Injection the dorsal bulbar } \\
\text { subconjunctival }\end{array}$ & Rabbits & $\begin{array}{l}\text { Reducing the infiltration of } \\
\text { inflammatory cells; promoting } \\
\text { corneal wound healing }\end{array}$ & $\begin{array}{l}\text { hAEC-CM (anti- } \\
\text { inflammatory factors) }\end{array}$ & [78] \\
\hline Corneal injury & Topically application & Mice & $\begin{array}{l}\text { Reducing corneal neovascularization; } \\
\text { suppressing corneal inflammatory } \\
\text { reactions }\end{array}$ & $\begin{array}{l}\text { hAEC-CM (anti- } \\
\text { inflammatory factors) }\end{array}$ & [79] \\
\hline $\begin{array}{l}\text { Premature ovarian } \\
\text { failure }\end{array}$ & Intraperitoneally injection & Mice & $\begin{array}{l}\text { Promoting the formation of } \\
\text { vascular; restoring ovarian function }\end{array}$ & $\begin{array}{l}\text { hAEC-CM (proangiogenic } \\
\text { factors) }\end{array}$ & [80] \\
\hline $\begin{array}{l}\text { Premature ovarian } \\
\text { failure }\end{array}$ & Ovarian injection & Mice & $\begin{array}{l}\text { Promoting follicular development; } \\
\text { inhibiting granulosa cell apoptosis; } \\
\text { restoring ovarian function }\end{array}$ & $\begin{array}{l}\text { hAEC-CM (TGF- } \beta 1 \text {; anti- } \\
\text { apoptotic effect) }\end{array}$ & [81] \\
\hline Chronic liver fibrosis & Intravenously injection & Mice & $\begin{array}{l}\text { Reducing collagen synthesis and } \\
\text { macrophage infiltration; inducing } \\
\text { macrophage toward M2 phenotype }\end{array}$ & $\begin{array}{l}\text { hAEC-CM (anti-fibrosis, } \\
\text { anti-inflammation) }\end{array}$ & [82] \\
\hline $\begin{array}{l}\text { Non-alcoholic } \\
\text { steatohepatitis }\end{array}$ & Intraperitoneally injection & Mice & $\begin{array}{l}\text { Reducing hepatic inflammation; } \\
\text { inhibiting liver fibrosis }\end{array}$ & $\begin{array}{l}\text { hAEC-CM (anti-inflammation; } \\
\text { anti-fibrosis) }\end{array}$ & [83] \\
\hline Myocardial infraction & Cardiac injection & Rats & $\begin{array}{l}\text { Regenerating myocardial tissue; } \\
\text { improving cardiac function }\end{array}$ & $\begin{array}{l}\text { hAEC-secreting } \\
\text { proangiogenic factors }\end{array}$ & [10] \\
\hline Wound healing & Topically injection & Rats & $\begin{array}{l}\text { Promoting the migration and } \\
\text { proliferation of fibroblasts; } \\
\text { accelerating wound healing; } \\
\text { inhibiting scar formation }\end{array}$ & hAEC-exosomes & {$[84,85]$} \\
\hline Wound healing & Topically injection & Mice & $\begin{array}{l}\text { Stimulating the migration and } \\
\text { proliferation of fibroblasts; } \\
\text { accelerating wound healing }\end{array}$ & hAEC-exosomes (miRNAs) & [86] \\
\hline $\begin{array}{l}\text { Idiopathic pulmonary } \\
\text { fibrosis }\end{array}$ & $\begin{array}{l}\text { Intravenously injection; } \\
\text { intranasal instillation }\end{array}$ & Mice & $\begin{array}{l}\text { Reducing lung inflammation } \\
\text { and fibrosis; improving tissue- } \\
\text { to-airspace ratio }\end{array}$ & $\begin{array}{l}\text { hAEC-exosomes (anti- } \\
\text { inflammation; anti-fibrosis) }\end{array}$ & [87] \\
\hline Chronic liver fibrosis & Intravenously injection & Mice & $\begin{array}{l}\text { Reducing collagen synthesis } \\
\text { and macrophage infiltration; } \\
\text { inducing macrophage toward } \\
\text { to M2 phenotype }\end{array}$ & $\begin{array}{l}\text { hAEC-EV (anti-fibrotic } \\
\text { proteins) }\end{array}$ & [82] \\
\hline $\begin{array}{l}\text { Premature ovarian } \\
\text { failure }\end{array}$ & Ovarian injection & Mice & $\begin{array}{l}\text { Inhibiting the apoptosis of } \\
\text { granulosa cells; repairing } \\
\text { ovarian function }\end{array}$ & $\begin{array}{l}\text { hAEC-exosomes } \\
\text { (miR-1246; anti-apoptosis) }\end{array}$ & [88] \\
\hline
\end{tabular}

that hAEC-derived exosomes (hAEC-exosomes) promoted the migration and proliferation of fibroblasts, downregulated collagen expression, and improved skin wound healing by inducing the formation of well-organized collagen fibers in rats $[84,85]$. Further study indicated that the effects of hAEC-exosomes were abolished by pretreating hAEC-exosomes with RNaseA, which indicates that miRNAs carried by exosomes play important roles in promoting wound healing [86]. In bleomycin-induced lung injury, hAEC-exosome transplantation reduced inflammation and fibrosis, and improved the tissue-to-airspace ratio by increasing macrophage phagocytosis, reducing neutrophil myeloperoxidase activity, and directly suppressing $\mathrm{T}$ cell proliferation. Further analysis found that some specific proteins comprising the cargo of hAEC-exosomes were mainly enriched in the MAPK signaling, apoptotic, and developmental biology pathways; however, the miRNAs were enriched in the PI3K-Akt, Ras, Hippo, TGF- $\beta$, and focal adhesion pathways [87]. Moreover, study also showed that proteins in hAEC-derived extracellular vesicles (hAEC-EVs) exerted anti-fibrosis function via modulating collagen synthesis and macrophage polarization in chronic liver fibrosis [82]. In addition, the target genes of miRNAs in hAEC-exosomes were mainly enriched in the phosphatidylinositol signaling system, PPAR signaling pathway, and apoptotic process pathway, which are involved in ovarian functional recovery mediated by hAECexosome transplantation [88].

Taken together, these results demonstrated that hAEC-derived cytokines and exosomes have important repair potential in the treatment of various diseases, imitating cell transplantation and avoiding the shortcomings 
of stem cell transplantation. Thus, exploring and identifying the most effective secretome components, including bioactive factors and extracellular vesicles/exosomes secreted by hAECs, will provide new treatment strategies for regenerative medicine.

\section{Immunomodulatory properties of hAECs}

In addition to the differentiation ability and paracrine function of hAECs, their powerful immunomodulatory properties also make their use in regenerative medicine a more reasonable option than the use of other cell types. Many studies have demonstrated that hAECs and hAEC-CM exert multiple immunosuppressive activities and anti-inflammatory properties. For example, hAECs suppressed both specific and non-specific $\mathrm{T}$ cell proliferation, decreased pro-inflammatory cytokine production, and inhibited the activation of stimulated $\mathrm{T}$ cells in vitro [94]. Furthermore, hAECs prevented monocyte-derived dendritic cell differentiation via cell-to-cell contact [95]. In addition, hAECs could produce a variety of immunoregulatory factors, including migration inhibitory factor (MIF), TGF- $\beta$, interleukin-10 (IL-10), and prostaglandin E2 (PGE2), contributing to suppress the function of inflammatory cells [96]. When hAECs were cocultured with peripheral blood mononuclear cells (PBMCs) derived from patients with unexplained recurrent spontaneous abortion, the proliferation of naïve $\mathrm{CD} 4 \mathrm{~T}$ cells was significantly inhibited, and the production of Th1 and Th17 cytokines was reduced [97, 98]. hAEC significantly attenuated the level of oxidative burst of neutrophils in coculture system [99]. Additionally, hAEC-CM inhibited the chemotactic activity of neutrophils and reduced the proliferation of both $\mathrm{T}$ and $\mathrm{B}$ cells after mitogenic stimulation [100].

These immunomodulatory properties have laid the foundation for the use of these cells in treating inflammatory and immune-based diseases, and encouraging results have been obtained in different disease models (Table 4). In ischemic stroke, hAEC transplantation significantly reduced inflammation, leading to the recovery of brain function [70] and the improvement of brain function after intracerebral hemorrhage (ICH) by reducing microglial activation and producing antiinflammatory factors [101]. In perinatal brain injury, hAEC transplantation reduced apoptosis and astrocyte areal coverage in the white matter, and increased the density of total and activated microglia via the release of trophic factors [102]. Moreover, hAECs mitigated fetal brain inflammation and reduced white matter injury via anti-inflammatory effects in the preterm ovine fetus, and they reduced the number of activated microglial cells in the white matter after repeated endotoxin exposure [103] and lipopolysaccharide (LPS)-induced intrauterine inflammation [104]. In multiple sclerosis, splenocytes from hAEC-treated mice showed a Th2 cytokine shift with significantly elevated interleukin-5 (IL-5) production [105]. In lung injury, a series of studies demonstrated that transplanted hAECs repaired lung function by decreasing macrophage and neutrophil infiltration, fibrosis, and collagen content; importantly, hAECs required normal host macrophage function to exert their reparative effects [106]. Further study showed that hAECs mediated lung function recovery by modulating macrophage recruitment and polarization in a paracrine manner [107]. Moreover, hAECs induced the maturation of non-Tregs into FoxP3-expressing Tregs mediated by TGF- $\beta$. Tregs are required for hAEC-mediated macrophage polarization and lung function recovery [108]. Another study also showed that the immunomodulatory effects of hAECs on macrophage phagocytic activity and T cell suppression are lipoxin-A4 (LXA4) dependent [109]. In addition, hAECs modulated the pulmonary inflammatory response to ventilation in preterm neonatal lambs and reduced acute lung injury [110]. Other studies reported that leukocyte infiltration of the lungs was not reduced by hAECs; however, the levels of inflammatory cytokines were reduced in intrauterine inflammationinduced lung injury [111] and in hyperoxia-induced neonatal lung injury [112]. Moreover, hAECs reduced the number of macrophages, dendritic cells, and natural killer cells and improved the tissue-to-airspace ratio and septal crest density in neonatal lung injury in a dose-dependent manner, regardless of the route of administration [113]. In early Achilles tendon defects, hAECs inhibited inflammatory cell infiltration, activated M2 macrophage subpopulation recruitment, and accelerated blood vessel and extracellular matrix remodeling by secreting immunoregulatory factors [68]. hAECs restored ovarian function by directly upregulating Treg cells in the spleen and reducing the inflammatory reaction in injured ovaries by modulating the polarization and function of macrophages in a paracrine manner [114]. In mice with experimental autoimmune thyroiditis (EAT) and systemic lupus erythematosus (SLE), hAECs prevented lymphocyte infiltration into the thyroid and improved thyroid follicular function by reducing the Th17/Treg cell ratio and increasing the proportion of B10 cells [115]. In addition, grafted hAECs accelerated diabetic wound healing and granulation tissue formation, partially by inducing differentiation of macrophages toward an M2 phenotype and promoting neovascularization in a paracrine manner [116]. In liver injury, hAECs induced the differentiation of macrophages toward an M2 phenotype, which was associated with a reduction in established hepatic fibrosis [117].

These immune remodeling processes, which are mediated by hAECs and soluble factors and extracellular vesicles secreted by hAECs, are of substantial importance to the regenerative process. Thus, hAECs have emerged as 
Table 4 Immunomodulatory function of hAECs in different diseases

\begin{tabular}{|c|c|c|c|c|c|}
\hline Diseases/focuses & $\begin{array}{l}\text { Transplantation method/ } \\
\text { dose }\end{array}$ & Species & Outcome & Repair mechanism & References \\
\hline Ischemic stroke & $\begin{array}{l}\text { Tail vein injection }\left(1 \times 10^{6}\right. \\
\text { hAECs); saphenous vein } \\
\text { injection }\left(5 \times 10^{6} \text { hAECs }\right)\end{array}$ & $\begin{array}{l}\text { Mice, } \\
\text { marmosets }\end{array}$ & $\begin{array}{l}\text { Reducing brain infarcted volume and } \\
\text { functional deficits; promoting long- } \\
\text { term functional recovery }\end{array}$ & $\begin{array}{l}\text { Inhibiting apoptosis and inflammation; } \\
\text { modulating immunosuppression }\end{array}$ & [70] \\
\hline $\begin{array}{l}\text { Intracerebral } \\
\text { hemorrhage }\end{array}$ & $\begin{array}{l}\text { Injection of cortex }\left(1 \times 10^{6}\right. \\
\text { hAECs) }\end{array}$ & Rats & $\begin{array}{l}\text { Reducing brain edema; ameliorating } \\
\text { the neurologic deficits }\end{array}$ & $\begin{array}{l}\text { Suppressing the activation of } \\
\text { microglia; reducing the inflammatory } \\
\text { response }\end{array}$ & [101] \\
\hline Perinatal brain injury & $\begin{array}{l}\text { Intravenously }\left(1 \times 10^{5}\right. \\
\text { hAECS })\end{array}$ & Mice & $\begin{array}{l}\text { Reducing microglia apoptosis; } \\
\text { increasing microglial phagocytic activity }\end{array}$ & $\begin{array}{l}\text { Modulating microglia via releasing } \\
\text { trophic factors }\end{array}$ & {$[102]$} \\
\hline Fetal brain injury & $\begin{array}{l}\text { Injection of brachial artery } \\
\text { catheter }\left(6 \times 10^{6} \text { hAECs }\right)\end{array}$ & Ewes & $\begin{array}{l}\text { Reducing white matter injury; } \\
\text { mitigating associated brain injury }\end{array}$ & $\begin{array}{l}\text { Inhibiting inflammation and apoptosis; } \\
\text { reducing the number of activated } \\
\text { microglial cells }\end{array}$ & {$[103,104]$} \\
\hline Multiple sclerosis & $\begin{array}{l}\text { Intravenously }\left(2 \times 10^{6}\right. \\
\text { hAECS })\end{array}$ & Mice & $\begin{array}{l}\text { Reducing monocyte/macrophage } \\
\text { infiltration and demyelination }\end{array}$ & $\begin{array}{l}\text { Mediating immunosuppression via } \\
\text { secreting TGF- } \beta \text { and PGE2; promoting } \\
\text { Th2 cytokine shift }\end{array}$ & {$[105]$} \\
\hline Lung injury & $\begin{array}{l}\text { Intraperitoneally }\left(4 \times 10^{6}\right. \\
\text { hAECS })\end{array}$ & Mice & $\begin{array}{l}\text { Decreasing neutrophil infiltration, } \\
\text { fibrosis, collagen content; repairing } \\
\text { lung function }\end{array}$ & $\begin{array}{l}\text { Depending on the function of host } \\
\text { macrophage }\end{array}$ & {$[106]$} \\
\hline Lung injury & $\begin{array}{l}\text { Intraperitoneally }\left(4 \times 10^{6}\right. \\
\text { hAECS })\end{array}$ & Mice & $\begin{array}{l}\text { Reducing macrophage infiltration; } \\
\text { increasing the number of } \mathrm{M} 2 \\
\text { macrophage }\end{array}$ & $\begin{array}{l}\text { Modulating macrophage polarization, } \\
\text { migration, and phagocytosis via } \\
\text { paracrine pathway }\end{array}$ & [107] \\
\hline Lung injury & $\begin{array}{l}\text { Intraperitoneally }\left(4 \times 10^{6}\right. \\
\text { hAECS) }\end{array}$ & Mice & $\begin{array}{l}\text { Mitigating lung inflammation and } \\
\text { fibrosis }\end{array}$ & $\begin{array}{l}\text { Tregs are required for } \mathrm{hAEC} \text {-mediated } \\
\text { macrophage polarization }\end{array}$ & [108] \\
\hline Lung injury & $\begin{array}{l}\text { Intraperitoneally }\left(4 \times 10^{6}\right. \\
\text { hAECS })\end{array}$ & Mice & $\begin{array}{l}\text { Reducing pro-inflammatory immune } \\
\text { cells; preventing lung injury }\end{array}$ & $\begin{array}{l}\text { Mediating immunomodulation partly } \\
\text { though LXA4 }\end{array}$ & [109] \\
\hline $\begin{array}{l}\text { Preterm neonatal } \\
\text { lung injury }\end{array}$ & $\begin{array}{l}\text { Intratracheally }\left(90 \times 10^{6}\right. \\
\text { hAECs) }\end{array}$ & Lambs & $\begin{array}{l}\text { Modulating the pulmonary } \\
\text { inflammatory response to ventilation; } \\
\text { reducing acute lung injury }\end{array}$ & Immunomodulatory effects & [110] \\
\hline Fetal lung injury & $\begin{array}{l}\text { Fetal jugular vein injection } \\
\left(90 \times 10^{6} \mathrm{hAECS}\right) \text {; fetal } \\
\text { intratracheal infusion } \\
\left(18 \times 10^{6} \mathrm{hAECs}\right)\end{array}$ & Sheep & $\begin{array}{l}\text { Attenuating the fetal pulmonary } \\
\text { inflammatory response }\end{array}$ & Reducing inflammatory cytokines & [111] \\
\hline Neonatal lung injury & $\begin{array}{l}\text { Intraperitoneally }\left(4.5 \times 10^{6}\right. \\
\text { hAECs) }\end{array}$ & Mice & $\begin{array}{l}\text { Partially reducing hyperoxia-induced in- } \\
\text { flammation and structural lung damage }\end{array}$ & Attenuating inflammation & [112] \\
\hline Neonatal lung injury & $\begin{array}{l}\text { Intravenously; intratracheal } \\
\text { infusion }\left(5 \times 10^{4} ; 7.5 \times 10^{4} \text {; }\right. \\
\left.1 \times 10^{5} \text { hAECS }\right)\end{array}$ & Mice & $\begin{array}{l}\text { Improving the tissue-to-airspace ratio } \\
\text { and the long-term of cardiorespiratory } \\
\text { function }\end{array}$ & $\begin{array}{l}\text { Reducing macrophages, dendritic cells, } \\
\text { and natural killer cells }\end{array}$ & [113] \\
\hline $\begin{array}{l}\text { Achilles tendon } \\
\text { injury }\end{array}$ & $\begin{array}{l}\text { In situ filling }\left(10 \times 10^{6}\right. \\
\text { hAECs) }\end{array}$ & Sheep & $\begin{array}{l}\text { Inhibiting inflammatory cell infiltration; } \\
\text { activating the M2 macrophage } \\
\text { subpopulation }\end{array}$ & $\begin{array}{l}\text { Regulating inflammatory and } \\
\text { immunomodulatory response; } \\
\text { accelerating blood vessel and ECM } \\
\text { remodeling }\end{array}$ & {$[68]$} \\
\hline $\begin{array}{l}\text { Autoimmune } \\
\text { ovarian disease }\end{array}$ & $\begin{array}{l}\text { Intravenously }\left(2 \times 10^{6}\right. \\
\text { hAECS })\end{array}$ & Mice & $\begin{array}{l}\text { Restoring ovarian function; } \\
\text { upregulating Treg cells; reducing the } \\
\text { inflammatory reaction }\end{array}$ & $\begin{array}{l}\text { Modulating macrophage function by } \\
\text { paracrine factors (TGF- } \beta \text { and MIF) }\end{array}$ & [114] \\
\hline $\begin{array}{l}\text { Experimental } \\
\text { autoimmune } \\
\text { thyroiditis; systemic } \\
\text { lupus erythematosus }\end{array}$ & $\begin{array}{l}\text { Intravenously }\left(1.5 \times 10^{6}\right. \\
\text { hAECs); intravenously } \\
\left(1.5 \times 10^{6} \text { hAECs }\right)\end{array}$ & Mice & $\begin{array}{l}\text { Preventing lymphocyte infiltration into } \\
\text { the thyroid; improving the damage of } \\
\text { thyroid follicular; reducing } \\
\text { immunoglobulin profiles }\end{array}$ & $\begin{array}{l}\text { Modulating the immune cell balance } \\
\text { by downregulating the ratios of Th17/ } \\
\text { Treg cells; upregulating the proportion } \\
\text { of B10 cells }\end{array}$ & {$[115]$} \\
\hline $\begin{array}{l}\text { Diabetic wound } \\
\text { healing }\end{array}$ & $\begin{array}{l}\text { Intradermally }\left(1 \times 10^{6}\right. \\
\text { hAECs })\end{array}$ & Mice & Promoting diabetic wound healing & $\begin{array}{l}\text { Reducing inflammation and } \\
\text { promoting neovascularization by } \\
\text { paracrine pathway }\end{array}$ & [116] \\
\hline Liver injury & $\begin{array}{l}\text { Intravenously }\left(2 \times 10^{6}\right. \\
\text { hAECs) }\end{array}$ & Mice & Reducing hepatic fibrosis & Inducing M2 macrophage phenotype & [117] \\
\hline
\end{tabular}

valid candidates for potential use in treating inflammatory and immune-based disorders.

\section{Clinical trials of hAEC transplantation}

On the basis of the preclinical animal studies mentioned above, a series of clinical trials to assess the safety and effectiveness of hAEC transplantation in the treatment of various diseases have been registered at http://ClinicalTrials.gov and are being conducted (Table 5).

Researchers conducted an early phase 1 clinical trial of hAEC transplantation in patients with intrauterine adhesion. Changes in the endometrial thickness, menstrual 
Table 5 Clinical trials of hAECs transplantation registered at http://ClinicalTrials.gov

\begin{tabular}{|c|c|c|c|c|c|c|c|c|c|}
\hline & Study & Disease & Design & Start date & Status & Phase & $\begin{array}{l}\text { Estimated } \\
\text { enrollment }\end{array}$ & Intervention & $\begin{array}{l}\text { ClinicalTrials.gov } \\
\text { identifier }\end{array}$ \\
\hline 1 & $\begin{array}{l}\text { Human Amniotic } \\
\text { Epithelial Cell in } \\
\text { Treatment of } \\
\text { Refractory Severe } \\
\text { Intrauterine } \\
\text { Adhesion }\end{array}$ & $\begin{array}{l}\text { Intrauterine } \\
\text { adhesion }\end{array}$ & $\begin{array}{l}\text { Safety and } \\
\text { effectiveness }\end{array}$ & $\begin{array}{l}\text { March } \\
2018\end{array}$ & $\begin{array}{l}\text { Not yet } \\
\text { recruiting }\end{array}$ & 1 & 20 & $\begin{array}{l}\text { Uterine cavity infusion } \\
\text { (100 million) }\end{array}$ & NCT03381807 \\
\hline 2 & $\begin{array}{l}\text { Human Amniotic } \\
\text { Epithelial Cells for } \\
\text { Asherman's } \\
\text { Syndrome }\end{array}$ & $\begin{array}{l}\text { Asherman's } \\
\text { syndrome }\end{array}$ & $\begin{array}{l}\text { Safety and } \\
\text { effectiveness }\end{array}$ & $\begin{array}{l}\text { October } \\
2017\end{array}$ & $\begin{array}{l}\text { Not yet } \\
\text { recruiting }\end{array}$ & 1 & 50 & $\begin{array}{l}\text { Biological amnion; } \\
\text { biological amnion } \\
\text { loaded with hAECs (100 } \\
\text { million); intravenous } \\
\text { infusion ( } 100 \text { million); } \\
\text { intrauterine infusion } \\
\text { (100 million); hydrogel } \\
\text { loaded with hAECs (100 } \\
\text { million) }\end{array}$ & NCT03223454 \\
\hline 3 & $\begin{array}{l}\text { A Therapeutic Trial } \\
\text { of Human Amniotic } \\
\text { Epithelial Cells } \\
\text { Transplantation for } \\
\text { Primary Ovarian } \\
\text { Insufficiency } \\
\text { Patients }\end{array}$ & $\begin{array}{l}\text { Primary } \\
\text { ovarian } \\
\text { insufficiency/ } \\
\text { premature } \\
\text { ovarian } \\
\text { failure/ } \\
\text { infertility }\end{array}$ & $\begin{array}{l}\text { Safety and } \\
\text { effectiveness }\end{array}$ & June 2020 & Recruiting & 1 & 36 & $\begin{array}{l}\text { Bilateral ovarian artery } \\
\text { infusion }\left(2 \times 10^{7} \text { cells }\right)\end{array}$ & NCT02912104 \\
\hline 4 & $\begin{array}{l}\text { Human Amniotic } \\
\text { Epithelial Cells } \\
\text { Treatment for } \\
\text { Ovarian } \\
\text { Insufficiency }\end{array}$ & $\begin{array}{l}\text { Premature } \\
\text { ovarian } \\
\text { failure }\end{array}$ & $\begin{array}{l}\text { Safety and } \\
\text { effectiveness }\end{array}$ & $\begin{array}{l}\text { December } \\
2017\end{array}$ & $\begin{array}{l}\text { Not yet } \\
\text { recruiting }\end{array}$ & $\begin{array}{l}\text { Not } \\
\text { applicable }\end{array}$ & 20 & $\begin{array}{l}\text { Minimally invasive } \\
\text { implantation ( } 200 \\
\text { million); intravenous } \\
\text { infusion ( } 100 \text { million for } \\
3 \text { times) }\end{array}$ & NCT03207412 \\
\hline 5 & $\begin{array}{l}\text { Human Amniotic } \\
\text { Epithelial Cells for } \\
\text { Treatment of } \\
\text { Bronchial Fistula }\end{array}$ & $\begin{array}{l}\text { Bronchial } \\
\text { fistula }\end{array}$ & $\begin{array}{l}\text { Therapeutic } \\
\text { potential }\end{array}$ & $\begin{array}{l}\text { October } \\
2016\end{array}$ & Recruiting & 1 & 10 & $\begin{array}{l}\text { Endoscopic injection of } \\
\text { hAECs to fistula }(3-5 \times \\
10^{7} \text { cells) }\end{array}$ & NCT02959333 \\
\hline 6 & $\begin{array}{l}\text { Effect of Human } \\
\text { Amniotic Epithelial } \\
\text { Cells on Children } \\
\text { With Spastic } \\
\text { Cerebral Palsy }\end{array}$ & $\begin{array}{l}\text { Spastic } \\
\text { cerebral } \\
\text { palsy }\end{array}$ & $\begin{array}{l}\text { Therapeutic } \\
\text { potential }\end{array}$ & April 2017 & $\begin{array}{l}\text { Enrolling } \\
\text { by } \\
\text { invitation }\end{array}$ & 1 & 10 & Intrathecal injection & NCT03107975 \\
\hline 7 & $\begin{array}{l}\text { Treatment of Non- } \\
\text { union of Limb Frac- } \\
\text { ture with Human } \\
\text { Amniotic Epithelial } \\
\text { Cells (hAECs) }\end{array}$ & $\begin{array}{l}\text { Non-union } \\
\text { fracture }\end{array}$ & $\begin{array}{l}\text { Safety and } \\
\text { efficacy }\end{array}$ & $\begin{array}{l}\text { December } \\
2017\end{array}$ & $\begin{array}{l}\text { Not yet } \\
\text { recruiting }\end{array}$ & $1 / 2$ & 36 & $\begin{array}{l}\text { Transplant to non-union } \\
\text { site ( } 50 \text { million) }\end{array}$ & NCT03031509 \\
\hline 8 & $\begin{array}{l}\text { hAECs Are } \\
\text { Preliminarily } \\
\text { Applied in } \\
\text { Allogeneic } \\
\text { Hematopoietic } \\
\text { Stem Cell } \\
\text { Transplantation }\end{array}$ & Leukemia & Observational & July 2020 & Recruiting & $\begin{array}{l}\text { Not } \\
\text { applicable }\end{array}$ & 30 & Unknown & NCT03759899 \\
\hline 9 & $\begin{array}{l}\text { Human Amniotic } \\
\text { Epithelial Cells } \\
\text { Prevent Acute } \\
\text { Graft-versus-host } \\
\text { Disease After } \\
\text { Hematopoietic } \\
\text { Stem Cell } \\
\text { Transplantation }\end{array}$ & $\begin{array}{l}\text { Acute graft- } \\
\text { versus-host } \\
\text { disease }\end{array}$ & $\begin{array}{l}\text { Safety and } \\
\text { efficacy }\end{array}$ & July 2020 & Recruiting & $\begin{array}{l}\text { Not } \\
\text { applicable }\end{array}$ & 27 & $\begin{array}{l}\text { Infusion of hAECs }(1 \times \\
10^{6}, 2 \times 10^{6}, 5 \times 10^{6} \text { cell/ } \\
\mathrm{kg})\end{array}$ & NCT03764228 \\
\hline
\end{tabular}

blood volume, and pregnancy rate will be observed to evaluate the safety and effectiveness of hAECs for treating intrauterine adhesion (NCT03381807). Another similar study was designed and conducted by using different interventional treatments with amnion, amnion loaded with hAECs, intravenous or intrauterine infusion of hAECs, and hydrogel loaded with hAECs to observe the therapeutic safety and effectiveness of 
hAECs in patients with intrauterine adhesion (NCT03223454).

Our research team designed and conducted a phase 1 clinical trial to evaluate the safety and effectiveness of bilateral ovarian artery infusion of hAECs into patients with POF. To date, we have recruited subjects and completed two trials of hAEC treatment in POF patients, and the results showed that hAEC transplantation increased the levels of estrogen and AMH, decreased FSH levels, and alleviated clinical symptoms (NCT02912104). Another clinical study of the application of hAECs to treat POF was also conducted via minimally invasive implantation. The outcomes were measured, including the ovarian volume and hormone levels (NCT03207412).

Investigators performed endoscopic injection of hAECs into bronchial fistula and observed the recovery of bronchial fistula and the resulting systemic reactions (NCT02959333). To evaluate the therapeutic potential of intrathecal hAECs in children with spastic cerebral palsy, functional status and spasticity were evaluated using the modified Ashworth scale (MAS) (NCT03107975). Phase $1 / 2$ clinical trials were designed, in which hAECs were transplanted after debridement, and the efficacy and safety were evaluated for the treatment of non-union fractures (NCT03031509). In allogeneic hematopoietic stem cell transplantation (allo-HSCT) for the treatment of leukemia, researchers tried to develop clinically applicable hAEC products and to evaluate their preliminary application in allo-HSCT (NCT03759899). Additionally, a dose escalation study evaluating the safety and efficacy of hAECs in preventing acute graft-versus-host disease after HSCT was conducted (NCT03764228).

In addition, a clinical trial registered by Sievert et al. in the Australian and New Zealand Clinical Trails Registry (ACTRN12616000437460) was conducted to evaluate the safety of intravenously administered hAECs for the treatment of liver fibrosis. In this phase 1 clinical trial, patients who received hAEC transplantation were closely monitored in the first $24 \mathrm{~h}$ postinfusion, and long-term follow-up included standard liver tests, transient electrography, and hepatic ultrasound [118]. Another study reported that allogeneic hAECs could be safely infused into babies with established bronchopulmonary dysplasia (BPD), and there were no adverse events related to cell administration [119]. Further clinical trials (ACTR N12618000920291) were registered and conducted to evaluate the effectiveness of intravenous hAEC infusion, including a trial to assess the cytokine profile, respiratory outcomes, and neonatal morbidity of infants [120]. In addition, a phase I clinical hAEC therapy of ischemic stroke (ACTRN12618000076279) was designed to determine the maximal tolerated dose (MTD) and assess cell safety. Fifteen stroke patients will be recruited and injected with hAECs by intravenous infusion. Safety and efficacy will be assessed by imaging and immunological assays [121]. These clinical trials will help to determine the safety and clinical benefits of hAEC-based therapy.

\section{Prospects for hAEC-based therapy}

The plasticity and therapeutic properties of hAECs are summarized in this review. Enhancing the repair potential of hAECs and achieving precise treatment need to be further considered.

To refine the manufacturing of hAECs and to maximize their capacity to promote functional recovery, there is an increasing need to improve our understanding of the biology and repair mechanism of hAECs. In consideration of special biological characteristics, primary hAECs have been widely used to repair damaged tissues in animal models and preclinical research. However, there are still some bottlenecks, including isolation protocols, EMT process, cell heterogeneity, and Measurement methods which hinder the clinical transformation of hAECs [122, 123]. Therefore, establishing a reasonable and optimal isolation protocol and agreeing upon strict definitions for hAECs will be necessary for their future application in tissue regeneration. Second, exploring new biology-guided approaches, including preconditioning and genetic manipulation, will facilitate their self-renewal and therapeutic properties of hAECs. For example, a recent study reported that vitamin $\mathrm{C}$ promoted the proliferation, migration, and self-renewal of hAECs. Furthermore, hAECs treated with vitamin C showed increased survival after transplantation and secreted a greater amount of growth factors, which improved the therapeutic potential of hAECs in mice with POF [124]. The plant-derived bioactive compound verbenalin significantly increased gene expression in hAECs, contributing to the enhanced neural repair potential of hAECs for AD [125].

On the other hand, paracrine function has been regarded as the main underlying mechanism in hAECs that mediates the recovery of function and immunomodulation; however, many factors can affect the paracrine potential of hAECs. A study revealed that primary and expanded hAECs displayed different differentiation capacity, immunosuppressive property, and paracrine effect, which could be exploited for different cellular therapeutic applications [29]. To enhance the repair potential and facilitate clinical application, some pretreatment approaches need to be further explored. A study showed that prolonged exposure of hAECs to the inflammatory cytokines interferon-gamma (INF- $\gamma$ ) and interleukinbeta (IL-1 $\beta$ ) may result in enhanced expression and secretion of immunomodulatory molecules, which are important in treating immune-related diseases [126]. Furthermore, a wide variety of studies should be conducted to validate the potential of hAEC-exosomes, in 
which miRNAs and proteins are contained as cargo, and to optimize culture conditions to obtain the optimal secretome with therapeutic value for application.

Currently, combining biomaterials with hAECs has become a new approach to prolong and strengthen their beneficial effects. Studies have demonstrated that biomaterial scaffolds could contribute to positively modulating the inflammatory response in the tissue and stimulating tissue regeneration. For example, the implantation of hAECs loaded on hydroxyapatite/ $\beta$-tricalcium phosphate scaffolds not only improved bone regeneration by direct participation but also reduced the early host immune response to the scaffolds [54]. Moreover, biomaterial scaffolds supported hAEC survival and differentiation after transplantation and provided a good microenvironment for tissue regeneration and functional recovery [127]. The latest study reported that poly(lactide-co-glycolide) (PLGA) could be used as a tendon biomimetic fleece for enhancing the differentiation and immunomodulation of transplanted hAECs in injured tendons [128]. Therefore, in vivo and long-term preclinical studies are needed to achieve translation from the bench to the bedside.

\section{Conclusions}

Regenerative medicine is a broad field of medicine in which stem cells are used to regenerate the function of injured organs and tissues. hAECs are easy to isolate, have low immunogenicity, and lack ethical concerns; thus, hAECs have extremely important therapeutic potential in regenerative medicine. The current review helps to further explain the different mechanisms of action for hAECbased cell therapy in treating various diseases. Importantly, the effects of hAEC paracrine function on the injured tissue microenvironment and the maintenance of balance of immunosuppression in recipients were crucial to the process of functional recovery. In the future, enhancing the therapeutic potential and developing new clinical protocols are needed for the application of hAEC-based strategies in regenerative medicine.

\footnotetext{
Abbreviations

3D: Three-dimensional; AD: Alzheimer's disease; AGN: Angiogenin; ALP: Alkaline phosphatase; AOD: Autoimmune ovarian disease; BDNF: Brainderived neurotrophic factor; bFGF: Basic fibroblast growth factor; BMP: Bone morphogenetic protein; BPD: Bronchopulmonary dysplasia; DA: Dopamine; EAE: Experimental autoimmune encephalomyelitis; EAT: Experimental autoimmune thyroiditis; EGF: Epidermal growth factor; EMT: Epithelial to mesenchymal transition; GMP: Good manufacturing procedure; hAECCM: Conditioned media of hAECs; hAEC-exosomes: hAEC-derived exosomes; hAECs: Human amniotic epithelial cells; hCECs: Human corneal epithelial cells; HGF: Hepatocyte growth factor; HLA: Human leukocyte antigens; HSCT: Hematopoietic stem cell transplantation; HSECs: Hepatic sinusoidal endothelial cells; ICH: Intracerebral hemorrhage; IGF: Insulin-like growth factor; IL-10: Interleukin-10; IL-1ß: Interleukin-1beta; IL-5: Interleukin-5; INF$\gamma$ : Interferon-gamma; ISCs: Insulin secreting cells; LPS: Lipopolysaccharide; LXA4: Lipoxin-A4; MAS: Modified Ashworth scale; miRNAs: MicroRNAs; MMP: Matrix metalloproteinase; MTD: Maximal tolerated dose; NASH: Nonalcoholic steatohepatitis; NGF: Nerve growth factor; NT-3: Neurotrophin-3; OCT-4: Octamer-binding transcription factor-4; OPN: Osteopontin;
}

PBMCs: Peripheral blood mononuclear cells; PD: Parkinson's disease; PDGFB: Platelet-derived growth factor B; PDX1: Pancreatic and duodenal homeobox-1; PGE2: Prostaglandin E2; POF: Premature ovarian failure; SAGM: Small airway growth medium; SCs: Schwann-like cells; SihCECs: Immortalized human corneal epithelial cells; SLE: Systemic lupus erythematosus; SSEA-3/4: Stage-specific embryonic antigen-3/4; SSM: Substitute serum medium; SSS: Serum substitute supplement; TGFß: TGF-beta; TRA: Tumor rejection antigen; VEGF: Vascular endothelial growth factor

\section{Acknowledgements}

Not applicable

\section{Authors' contributions}

QZ conceived and drafted the manuscript. DL read and approved this manuscript. The author(s) read and approved the final manuscript.

\section{Funding}

This work was supported by the National Key Research and Developmental Program of China (2018YFC1004800 and 2018YFC1004802), the National Natural Science Foundation of China (81701397 and 81971334), the Shanghai Municipal Council for Science and Technology (18410721200 and 20ZR1463200), and the Opening Fund of Key Laboratory of the Diagnosis and Treatment Research of Reproductive Disorders of Zhejiang Province (no. 2018001).

\section{Availability of data and materials} Not applicable

\section{Ethics approval and consent to participate}

Not applicable

\section{Consent for publication}

Not applicable

\section{Competing interests}

The authors declare that they have no competing interests.

Received: 1 July 2020 Accepted: 24 September 2020

Published online: 15 October 2020

\section{References}

1. Xu H, Zhang J, Tsang KS, Yang H, Gao WQ. Therapeutic potential of human amniotic epithelial cells on injuries and disorders in the central nervous system. Stem Cells Int. 2019;2019:5432301.

2. Kim KY, Suh YH, Chang KA. Therapeutic effects of human amniotic epithelial stem cells in a transgenic mouse model of Alzheimer's disease. Int J Mol Sci. 2020;21(7):2658

3. Wu ZY, Hui GZ, Lu Y, Wu X, Guo LH. Transplantation of human amniotic epithelial cells improves hindlimb function in rats with spinal cord injury. Chin Med J. 2006;119(24):2101-7.

4. van den Heuij LG, Fraser M, Miller SL, Jenkin G, Wallace EM, Davidson JO, et al. Delayed intranasal infusion of human amnion epithelial cells improves white matter maturation after asphyxia in preterm fetal sheep. J Cereb Blood Flow Metab. 2019;39(2):223-39.

5. He F, Zhou A, Feng S. Use of human amniotic epithelial cells in mouse models of bleomycin-induced lung fibrosis: a systematic review and metaanalysis. PLoS One. 2018;13(5):e0197658.

6. Hodges RJ, Lim R, Jenkin G, Wallace EM. Amnion epithelial cells as a candidate therapy for acute and chronic lung injury. Stem Cells Int. 2012; 2012:709763.

7. Andrewartha N, Yeoh G. Human amnion epithelial cell therapy for chronic liver disease. Stem Cells Int. 2019;2019:8106482.

8. Lebreton F, Lavallard V, Bellofatto K, Bonnet R, Wassmer $\mathrm{CH}$, Perez L, et al. Insulin-producing organoids engineered from islet and amniotic epithelial cells to treat diabetes. Nat Commun. 2019;10(1):4491.

9. Liu J, Hua R, Gong Z, Shang B, Huang Y, Guo L, et al. Human amniotic epithelial cells inhibit CD4+ T cell activation in acute kidney injury patients by influencing the miR-101-c-Rel-IL-2 pathway. Mol Immunol. 2017;81:76-84. 
10. Song YS, Joo HW, Park IH, Shen GY, Lee Y, Shin JH, et al. Transplanted human amniotic epithelial cells secrete paracrine proangiogenic cytokines in rat model of myocardial infarction. Cell Transplant. 2015;24(10):2055-64.

11. Zhao B, Liu JQ, Zheng Z, Zhang J, Wang SY, Han SC, et al. Human amniotic epithelial stem cells promote wound healing by facilitating migration and proliferation of keratinocytes via ERK, JNK and AKT signaling pathways. Cell Tissue Res. 2016;365(1):85-99.

12. Zheng $X$, Jiang Z, Zhou A, Yu L, Quan M, Cheng H. Pathologic changes of wound tissue in rats with stage III pressure ulcers treated by transplantation of human amniotic epithelial cells. Int J Clin Exp Pathol. 2015;8(10):12284-91.

13. Li B, Zhang Q, Sun J, Lai D. Human amniotic epithelial cells improve fertility in an intrauterine adhesion mouse model. Stem Cell Res Ther. 2019;10(1):257.

14. Zhang Q, Xu M, Yao X, Li T, Wang Q, Lai D. Human amniotic epithelial cells inhibit granulosa cell apoptosis induced by chemotherapy and restore the fertility. Stem Cell Res Ther. 2015;6:152.

15. Miki T, Lehmann T, Cai H, Stolz DB, Strom SC. Stem cell characteristics of amniotic epithelial cells. Stem Cells. 2005;23(10):1549-59.

16. Miki T. Stem cell characteristics and the therapeutic potential of amniotic epithelial cells. Am J Reprod Immunol. 2018;80(4):e13003.

17. Ilancheran S, Michalska A, Peh G, Wallace EM, Pera M, Manuelpillai U. Stem cells derived from human fetal membranes display multilineage differentiation potential. Biol Reprod. 2007;77(3):577-88.

18. Wassmer $\mathrm{CH}$, Berishvili E. Immunomodulatory properties of amniotic membrane derivatives and their potential in regenerative medicine. Curr Diab Rep. 2020;20(8):31.

19. Yang PJ, Yuan WX, Liu J, Li JY, Tan B, Qiu C, et al. Biological characterization of human amniotic epithelial cells in a serum-free system and their safety evaluation. Acta Pharmacol Sin. 2018;39(8):1305-16.

20. Trosan P, Smeringaiova I, Brejchova K, Bednar J, Benada O, Kofronova O, et al. The enzymatic de-epithelialization technique determines denuded amniotic membrane integrity and viability of harvested epithelial cells. PLoS One. 2018;13(3):e0194820.

21. Tabatabaei M, Mosaffa N, Nikoo S, Bozorgmehr M, Ghods R, Kazemnejad S, et al. Isolation and partial characterization of human amniotic epithelial cells: the effect of trypsin. Avicenna J Med Biotechnol. 2014;6(1):10-20.

22. Motedayyen H, Esmaeil N, Tajik N, Khadem F, Ghotloo S, Khani B, et al, Method and key points for isolation of human amniotic epithelial cells with high yield, viability and purity. BMC Res Notes. 2017;10(1):552

23. Gramignoli R, Srinivasan RC, Kannisto K, Strom SC. Isolation of human amnion epithelial cells according to current good manufacturing procedures. Curr Protoc Stem Cell Biol. 2016;37:1E 10 1-1E 3.

24. Fatimah SS, Tan GC, Chua KH, Tan AE, Hayati AR. Effects of epidermal growth factor on the proliferation and cell cycle regulation of cultured human amnion epithelial cells. J Biosci Bioeng. 2012;114(2):220-7.

25. Simat SF, Chua KH, Abdul Rahman H, Tan AE, Tan GC. The stemness gene expression of cultured human amniotic epithelial cells in serial passages. Med J Malaysia. 2008;63(Suppl A):53-4.

26. Alcaraz A, Mrowiec A, Insausti CL, Garcia-Vizcaino EM, Ruiz-Canada C, LopezMartinez MC, et al. Autocrine TGF-beta induces epithelial to mesenchymal transition in human amniotic epithelial cells. Cell Transplant. 2013;22(8):1351-67.

27. Janzen C, Sen S, Lei MY, Gagliardi de Assumpcao M, Challis J, Chaudhuri G. The role of epithelial to mesenchymal transition in human amniotic membrane rupture. J Clin Endocrinol Metab. 2017;102(4):1261-9.

28. Evron A, Goldman S, Shalev E. Human amniotic epithelial cells cultured in substitute serum medium maintain their stem cell characteristics for up to four passages. Int J Stem Cells. 2011;4(2):123-32.

29. Pratama G, Vaghjiani V, Tee JY, Liu YH, Chan J, Tan C, et al. Changes in culture expanded human amniotic epithelial cells: implications for potential therapeutic applications. PLoS One. 2011;6(11):e26136.

30. Easley CA, Miki T, Castro CA, Ozolek JA, Minervini CF, Ben-Yehudah A, et al. Human amniotic epithelial cells are reprogrammed more efficiently by induced pluripotency than adult fibroblasts. Cell Reprogram. 2012;14(3):193-203.

31. Luo H, Huang X, Huang F, Liu X. Transversal inducing differentiation of human amniotic epithelial cells into hepatocyte-like cells. Zhong Nan Da Xue Xue Bao Yi Xue Ban. 2011;36(6):525-31.

32. Marongiu F, Gramignoli R, Dorko K, Miki T, Ranade AR, Paola Serra M, et al. Hepatic differentiation of amniotic epithelial cells. Hepatology. 2011;53(5): 1719-29.

33. Maymo JL, Riedel R, Perez-Perez A, Magatti M, Maskin B, Duenas JL, et al. Proliferation and survival of human amniotic epithelial cells during their hepatic differentiation. PLoS One. 2018;13(1):e0191489.
34. Lin JS, Zhou L, Sagayaraj A, Jumat NH, Choolani M, Chan JK, et al. Hepatic differentiation of human amniotic epithelial cells and in vivo therapeutic effect on animal model of cirrhosis. J Gastroenterol Hepatol. 2015;30(1 1):1673-82.

35. Serra M, Marongiu M, Contini A, Miki T, Cadoni E, Laconi E, et al. Evidence of amniotic epithelial cell differentiation toward hepatic sinusoidal endothelial cells. Cell Transplant. 2018;27(1):23-30.

36. Okere B, Alviano F, Costa R, Quaglino D, Ricci F, Dominici M, et al. In vitro differentiation of human amniotic epithelial cells into insulin-producing 3D spheroids. Int J Immunopathol Pharmacol. 2015;28(3):390-402.

37. Balaji S, Zhou Y, Opara EC, Soker S. Combinations of activin A or nicotinamide with the pancreatic transcription factor PDX1 support differentiation of human amnion epithelial cells toward a pancreatic lineage. Cell Reprogram. 2017;19(4):255-62.

38. Wang J, Peng L, Lu GX. Stem cell characteristics and islet differentiation potential of human amniotic epithelial cells. Nan Fang Yi Ke Da Xue Xue Bao. 2011;31(9):1484-7.

39. Peng L, Wang J, Lu G. Involvement of gene methylation changes in the differentiation of human amniotic epithelial cells into islet-like cell clusters. DNA Cell Biol. 2014;33(9):591-8.

40. Balaji S, Zhou Y, Ganguly A, Opara EC, Soker S. The combined effect of PDX1, epidermal growth factor and poly-L-ornithine on human amnion epithelial cells' differentiation. BMC Dev Biol. 2016;16:8.

41. Huang GL, Zhang NN, Wang JS, Yao L, Zhao YJ, Wang YY.

Transdifferentiation of human amniotic epithelial cells into acinar cells using a double-chamber system. Cell Reprogram. 2012;14(4):377-83.

42. Zhao YJ, Fang N, Chen DX, Yu LM, Yu HF, Zhao CH. Study on inducing differentiation of human amniotic epithelial cells into insulin secreting cells in vitro. Zhongguo Ying Yong Sheng Li Xue Za Zhi. 2012;28(2):139-43.

43. Wang F, Liu XJ, Wang H, Wu WC, Zheng A. Preliminary research on the differentiation of human amniotic epithelial cells into female germ cells. Sichuan Da Xue Xue Bao Yi Xue Ban. 2013;44(3):357-61.

44. Wang $H$, Wang F, Bai LP, Mo XY, Tang HY, Zheng A. Trans-differentiation of human amniotic epithelial cells into follicle-like structure. Sichuan Da Xue Xue Bao Yi Xue Ban. 2017:48(4):531-6.

45. Evron A, Goldman S, Shalev E. Human amniotic epithelial cells differentiate into cells expressing germ cell specific markers when cultured in medium containing serum substitute supplement. Reprod Biol Endocrinol. 2012;10: 108.

46. Liu X, Chen J, Zhou Q, Xu W, Ye L, Zhou J, et al. Differentiation of human amniotic epithelial cells (HAECs) into corneal epithelial cells induced by coculture of HAECs and corneal epithelial cells in vitro. Xi Bao Yu Fen Zi Mian Yi Xue Za Zhi. 2017;33(4):508-12.

47. Zhou Q, Liu XY, Ruan YX, Wang L, Jiang MM, Wu J, et al. Construction of corneal epithelium with human amniotic epithelial cells and repair of limbal deficiency in rabbit models. Hum Cell. 2015;28(1):22-36.

48. Yao M, Chen J, Yang XX, Zhang XL, Ji QS, Zhou Q, et al. Differentiation of human amniotic epithelial cells into corneal epithelial-like cells in vitro. Int J Ophthalmol. 2013;6(5):564-72.

49. Yang SP, Yang $X Z$, Cao GP. Conjunctiva reconstruction by induced differentiation of human amniotic epithelial cells. Genet Mol Res. 2015;14(4): 13823-34.

50. Niknejad H, Peirovi H, Ahmadiani A, Ghanavi J, Jorjani M. Differentiation factors that influence neuronal markers expression in vitro from human amniotic epithelial cells. Eur Cell Mater. 2010;19:22-9.

51. Ferdousi F, Sasaki K, Uchida Y, Ohkohchi N, Zheng YW, Isoda H. Exploring the potential role of rosmarinic acid in neuronal differentiation of human amnion epithelial cells by microarray gene expression profiling. Front Neurosci. 2019;13:779.

52. Garcia-Castro IL, Garcia-Lopez G, Avila-Gonzalez D, Flores-Herrera H, MolinaHernandez A, Portillo W, et al. Markers of pluripotency in human amniotic epithelial cells and their differentiation to progenitor of cortical neurons. PLoS One. 2015;10(12):e0146082

53. Zhu S, Li J, Zhu Q, Dai T, He B, Zhou X, et al. Differentiation of human amniotic epithelial cells into Schwann-like cells via indirect co-culture with Schwann cells in vitro. Mol Med Rep. 2015;11(2):1221-7.

54. Jiawen S, Jianjun Z, Jiewen D, Dedong Y, Hongbo Y, Jun S, et al. Osteogenic differentiation of human amniotic epithelial cells and its application in alveolar defect restoration. Stem Cells Transl Med. 2014;3(12):1504-13.

55. Zhou J, Yu G, Cao C, Pang J, Chen X. Bone morphogenetic protein-7 promotes chondrogenesis in human amniotic epithelial cells. Int Orthop. 2011;35(6):941-8. 
56. Luan F, Ma K, Mao J, Yang F, Zhang M, Luan H. Differentiation of human amniotic epithelial cells into osteoblasts is induced by mechanical stretch via the Wnt/betacatenin signalling pathway. Mol Med Rep. 2018;18(6):5717-25.

57. Murphy SV, Lim R, Heraud P, Cholewa M, Le Gros M, de Jonge MD, et al. Human amnion epithelial cells induced to express functional cystic fibrosis transmembrane conductance regulator. PLoS One. 2012;7(9):e46533.

58. Han X, Wan Q, Wu W, Zheng A, Li L, Liu X. Activin A and BMP-4 induce cardiomyocyte-like cells differentiation of human amniotic epithelial cells. Sheng Wu Yi Xue Gong Cheng Xue Za Zhi. 2011;28(6):1217-22.

59. Fatimah SS, Chua K, Tan GC, Azmi TI, Tan AE, Abdul RH. Organotypic culture of human amnion cells in air-liquid interface as a potential substitute for skin regeneration. Cytotherapy. 2013;15(8):1030-41.

60. Kakishita K, Elwan MA, Nakao N, Itakura T, Sakuragawa N. Human amniotic epithelial cells produce dopamine and survive after implantation into the striatum of a rat model of Parkinson's disease: a potential source of donor for transplantation therapy. Exp Neurol. 2000;165(1):27-34.

61. Liu T, Wu J, Huang Q, Hou Y, Jiang Z, Zang S, et al. Human amniotic epithelial cells ameliorate behavioral dysfunction and reduce infarct size in the rat middle cerebral artery occlusion model. Shock. 2008;29(5):603-11.

62. Xue SR, Chen CF, Dong WL, Hui GZ, Liu TJ, Guo LH. Intracerebroventricular transplantation of human amniotic epithelial cells ameliorates spatial memory deficit in the doubly transgenic mice coexpressing APPswe and PS1DeltaE9-deleted genes. Chin Med J. 2011;124(17):2642-8.

63. Hodges RJ, Jenkin G, Hooper SB, Allison B, Lim R, Dickinson H, et al. Human amnion epithelial cells reduce ventilation-induced preterm lung injury in fetal sheep. Am J Obstet Gynecol. 2012;206(5):448 e8-15.

64. Wang F, Wang L, Yao X, Lai D, Guo L. Human amniotic epithelial cells can differentiate into granulosa cells and restore folliculogenesis in a mouse model of chemotherapy-induced premature ovarian failure. Stem Cell Res Ther. 2013;4(5):124.

65. Fang $\mathrm{CH}$, Jin J, Joe JH, Song YS, So Bl, Lim SM, et al. In vivo differentiation of human amniotic epithelial cells into cardiomyocyte-like cells and cell transplantation effect on myocardial infarction in rats: comparison with cord blood and adipose tissue-derived mesenchymal stem cells. Cell Transplant. 2012;21(8):1687-96.

66. Zhang NN, Huang GL, Han QB, Hu X, Yi J, Yao L, et al. Functional regeneration of irradiated salivary glands with human amniotic epithelial cells transplantation. Int J Clin Exp Pathol. 2013;6(10):2039-47.

67. Yuge I, Takumi Y, Koyabu K, Hashimoto S, Takashima S, Fukuyama T, et al. Transplanted human amniotic epithelial cells express connexin 26 and Na-Kadenosine triphosphatase in the inner ear. Transplantation. 2004;77(9):1452-4.

68. Barboni B, Russo V, Gatta V, Bernabo N, Berardinelli P, Mauro A, et al. Therapeutic potential of hAECs for early Achilles tendon defect repair through regeneration. J Tissue Eng Regen Med. 2018;12(3):e1594-e608.

69. Wu Z, Hui G, Lu Y, Liu T, Huang Q, Guo L. Human amniotic epithelial cells express specific markers of nerve cells and migrate along the nerve fibers in the corpus callosum. Neural Regen Res. 2012;7(1):41-5.

70. Evans MA, Lim R, Kim HA, Chu HX, Gardiner-Mann CV, Taylor KWE, et al. Acute or delayed systemic administration of human amnion epithelial cells improves outcomes in experimental stroke. Stroke. 2018;49(3):700-9.

71. Ozaki Y, Nishimura M, Sekiya K, Suehiro F, Kanawa M, Nikawa H, et al. Comprehensive analysis of chemotactic factors for bone marrow mesenchymal stem cells. Stem Cells Dev. 2007;16(1):119-29.

72. Srinivasan RC, Kannisto K, Strom SC, Gramignoli R. Evaluation of different routes of administration and biodistribution of human amnion epithelial cells in mice. Cytotherapy. 2019;21(1):113-24.

73. Huang X, Luo H, Huang FZ, Liu XY. Labeling and tracking human amniotic epithelial cells with green fluorescent protein in an adeno-associated virus vector. Cell Mol Biol Lett. 2011;16(2):201-13.

74. Uchida S, Inanaga Y, Kobayashi M, Hurukawa S, Araie M, Sakuragawa N. Neurotrophic function of conditioned medium from human amniotic epithelial cells. J Neurosci Res. 2000;62(4):585-90.

75. Uchida S, Suzuki Y, Araie M, Kashiwagi K, Otori Y, Sakuragawa N. Factors secreted by human amniotic epithelial cells promote the survival of rat retinal ganglion cells. Neurosci Lett. 2003:341(1):1-4.

76. Wu Q, Fang T, Lang H, Chen M, Shi P, Pang X, et al. Comparison of the proliferation, migration and angiogenic properties of human amniotic epithelial and mesenchymal stem cells and their effects on endothelial cells. Int J Mol Med. 2017;39(4):918-26.

77. Kakishita K, Nakao N, Sakuragawa N, Itakura T. Implantation of human amniotic epithelial cells prevents the degeneration of nigral dopamine neurons in rats with 6-hydroxydopamine lesions. Brain Res. 2003;980(1):48-56.
78. Kim TH, Park YW, Ahn JS, Ahn JT, Kim SE, Jeong MB, et al. Effects of conditioned media from human amniotic epithelial cells on corneal alkali injuries in rabbits. J Vet Sci. 2013;14(1):61-7.

79. Kamiya K, Wang M, Uchida S, Amano S, Oshika T, Sakuragawa N, et al. Topical application of culture supernatant from human amniotic epithelial cells suppresses inflammatory reactions in cornea. Exp Eye Res. 2005;80(5):671-9.

80. Yao X, Guo Y, Wang Q, Xu M, Zhang Q, Li T, et al. The paracrine effect of transplanted human amniotic epithelial cells on ovarian function improvement in a mouse model of chemotherapy-induced primary ovarian insufficiency. Stem Cells Int. 2016;2016:4148923.

81. Zhang Q, Bu S, Sun J, Xu M, Yao X, He K, et al. Paracrine effects of human amniotic epithelial cells protect against chemotherapy-induced ovarian damage. Stem Cell Res Ther. 2017;8(1):270.

82. Alhomrani M, Correia J, Zavou M, Leaw B, Kuk N, Xu R, et al. The human amnion epithelial cell secretome decreases hepatic fibrosis in mice with chronic liver fibrosis. Front Pharmacol. 2017;8:748.

83. Kuk N, Hodge A, Sun Y, Correia J, Alhomrani M, Samuel C, et al. Human amnion epithelial cells and their soluble factors reduce liver fibrosis in murine non-alcoholic steatohepatitis. J Gastroenterol Hepatol. 2019;34(8):1441-9.

84. Zhao B, Zhang Y, Han S, Zhang W, Zhou Q, Guan H, et al. Exosomes derived from human amniotic epithelial cells accelerate wound healing and inhibit scar formation. J Mol Histol. 2017;48(2):121-32.

85. Zhao B, Wu GF, Zhang YJ, Zhang W, Yang FF, Xiao D, et al. Effects of human amniotic epithelial stem cells-derived exosomes on healing of wound with fullthickness skin defect in rats. Zhonghua Shao Shang Za Zhi. 2017;33(1):18-23.

86. Zhao B, Li X, Shi X, Shi X, Zhang W, Wu G, et al. Exosomal microRNAs derived from human amniotic epithelial cells accelerate wound healing by promoting the proliferation and migration of fibroblasts. Stem Cells Int. 2018;2018:5420463.

87. Tan JL, Lau SN, Leaw B, Nguyen HPT, Salamonsen LA, Saad MI, et al. Amnion epithelial cell-derived exosomes restrict lung injury and enhance endogenous lung repair. Stem Cells Transl Med. 2018;7(2):180-96.

88. Zhang Q, Sun J, Huang Y, Bu S, Guo Y, Gu T, et al. Human amniotic epithelial cell-derived exosomes restore ovarian function by transferring microRNAs against apoptosis. Mol Ther Nucleic Acids. 2019;16:407-18.

89. Hodge A, Lourensz D, Vaghijani V, Nguyen $\mathrm{H}$, Tchongue J, Wang B, et al. Soluble factors derived from human amniotic epithelial cells suppress collagen production in human hepatic stellate cells. Cytotherapy. 2014;16(8):1132-44.

90. Lim R, Chan ST, Tan JL, Mockler JC, Murphy SV, Wallace EM. Preterm human amnion epithelial cells have limited reparative potential. Placenta. 2013; 34(6):486-92.

91. Zhu D, Muljadi R, Chan ST, Vosdoganes P, Lo C, Mockler JC, et al. Evaluating the impact of human amnion epithelial cells on angiogenesis. Stem Cells Int. 2016;2016:4565612

92. Prathipati P, Nandi SS, Mishra PK. Stem cell-derived exosomes, autophagy, extracellular matrix turnover, and miRNAs in cardiac regeneration during stem cell therapy. Stem Cell Rev Rep. 2017;13(1):79-91.

93. Yuan KM, Zhang PH, Qi SS, Zhu QZ, Li P. Emerging role for exosomes in the progress of stem cell research. Am J Med Sci. 2018;356(5):481-6.

94. McDonald CA, Payne NL, Sun G, Moussa L, Siatskas C, Lim R, et al. Immunosuppressive potential of human amnion epithelial cells in the treatment of experimental autoimmune encephalomyelitis. J Neuroinflammation. 2015;12:112.

95. Magatti M, Caruso M, De Munari S, Vertua E, De D, Manuelpillai U, et al. Human amniotic membrane-derived mesenchymal and epithelial cells exert different effects on monocyte-derived dendritic cell differentiation and function. Cell Transplant. 2015;24(9):1733-52.

96. Koizumi NJ, Inatomi TJ, Sotozono CJ, Fullwood NJ, Quantock AJ, Kinoshita S. Growth factor mRNA and protein in preserved human amniotic membrane. Curr Eye Res. 2000;20(3):173-7.

97. Motedayyen H, Zarnani AH, Tajik N, Ghotloo S, Rezaei A. Immunomodulatory effects of human amniotic epithelial cells on naive CD4(+) T cells from women with unexplained recurrent spontaneous abortion. Placenta. 2018;71:31-40.

98. Motedayyen H, Rezaei A, Zarnani AH, Tajik N. Human amniotic epithelial cells inhibit activation and pro-inflammatory cytokines production of naive CD4+ T cells from women with unexplained recurrent spontaneous abortion. Reprod Biol. 2018;18(2):182-8.

99. Alipour R, Motedayyen H, Sereshki N, Rafiee M, Alsahebfosul F, Pourazar A. Human amniotic epithelial cells affect the functions of neutrophils. Int J Stem Cells. 2020;13(2):212-20. 
100. Li H, Niederkorn JY, Neelam S, Mayhew E, Word RA, McCulley JP, et al. Immunosuppressive factors secreted by human amniotic epithelial cells. Invest Ophthalmol Vis Sci. 2005;46(3):900-7.

101. Liang H, Guan D, Gao A, Yin Y, Jing M, Yang L, et al. Human amniotic epithelial stem cells inhibit microglia activation through downregulation of tumor necrosis factor-alpha, interleukin-1 beta and matrix metalloproteinase12 in vitro and in a rat model of intracerebral hemorrhage. Cytotherapy. 2014;16(4):523-34

102. Leaw B, Zhu D, Tan J, Muljadi R, Saad MI, Mockler JC, et al. Human amnion epithelial cells rescue cell death via immunomodulation of microglia in a mouse model of perinatal brain injury. Stem Cell Res Ther. 2017;8(1):46.

103. Yawno T, Sabaretnam T, Li J, McDonald C, Lim R, Jenkin G, et al. Human amnion epithelial cells protect against white matter brain injury after repeated endotoxin exposure in the preterm ovine fetus. Cell Transplant. 2017;26(4):541-53.

104. Yawno T, Schuilwerve J, Moss TJ, Vosdoganes P, Westover AJ, Afandi E, et al. Human amnion epithelial cells reduce fetal brain injury in response to intrauterine inflammation. Dev Neurosci. 2013;35(2-3):272-82.

105. Liu YH, Vaghjiani V, Tee JY, To K, Cui P, Oh DY, et al. Amniotic epithelial cells from the human placenta potently suppress a mouse model of multiple sclerosis. PLoS One. 2012;7(4):e35758.

106. Murphy SV, Shiyun SC, Tan JL, Chan S, Jenkin G, Wallace EM, et al. Human amnion epithelial cells do not abrogate pulmonary fibrosis in mice with impaired macrophage function. Cell Transplant. 2012;21(7):1477-92.

107. Tan JL, Chan ST, Wallace EM, Lim R. Human amnion epithelial cells mediate lung repair by directly modulating macrophage recruitment and polarization. Cell Transplant. 2014;23(3):319-28.

108. Tan JL, Chan ST, Lo CY, Deane JA, McDonald CA, Bernard CC, et al. Amnion cell-mediated immune modulation following bleomycin challenge: controlling the regulatory T cell response. Stem Cell Res Ther. 2015;6:8

109. Tan JL, Tan YZ, Muljadi R, Chan ST, Lau SN, Mockler JC, et al. Amnion epithelial cells promote lung repair via lipoxin A4. Stem Cells Transl Med. 2017;6(4):1085-95.

110. Melville JM, McDonald CA, Bischof RJ, Polglase GR, Lim R, Wallace EM, et al. Human amnion epithelial cells modulate the inflammatory response to ventilation in preterm lambs. PLoS One. 2017;12(3):e0173572.

111. Vosdoganes P, Hodges RJ, Lim R, Westover AJ, Acharya RY, Wallace EM, et al. Human amnion epithelial cells as a treatment for inflammation-induced fetal lung injury in sheep. Am J Obstet Gynecol. 2011;205(2):156 e26-33.

112. Vosdoganes P, Lim R, Koulaeva E, Chan ST, Acharya R, Moss TJ, et al. Human amnion epithelial cells modulate hyperoxia-induced neonatal lung injury in mice. Cytotherapy. 2013;15(8):1021-9.

113. Zhu D, Tan J, Maleken AS, Muljadi R, Chan ST, Lau SN, et al. Human amnion cells reverse acute and chronic pulmonary damage in experimental neonatal lung injury. Stem Cell Res Ther. 2017;8(1):257.

114. Zhang Q, Huang Y, Sun J, Gu T, Shao X, Lai D. Immunomodulatory effect of human amniotic epithelial cells on restoration of ovarian function in mice with autoimmune ovarian disease. Acta Biochim Biophys Sin Shanghai. 2019;51(8):845-55.

115. Tan B, Yuan W, Li J, Yang P, Ge Z, Liu J, et al. Therapeutic effect of human amniotic epithelial cells in murine models of Hashimoto's thyroiditis and systemic lupus erythematosus. Cytotherapy. 2018;20(10):1247-58.

116. Zheng Y, Zheng S, Fan X, Li L, Xiao Y, Luo P, et al. Amniotic epithelial cells accelerate diabetic wound healing by modulating inflammation and promoting neovascularization. Stem Cells Int. 2018;2018:1082076.

117. Manuelpillai U, Lourensz D, Vaghjiani V, Tchongue J, Lacey D, Tee JY, et al. Human amniotic epithelial cell transplantation induces markers of alternative macrophage activation and reduces established hepatic fibrosis. PLoS One. 2012;7(6):e38631.

118. Lim R, Hodge A, Moore G, Wallace EM, Sievert W. A pilot study evaluating the safety of intravenously administered human amnion epithelial cells for the treatment of hepatic fibrosis. Front Pharmacol. 2017;8:549.

119. Lim R, Malhotra A, Tan J, Chan ST, Lau S, Zhu D, et al. First-in-human administration of allogeneic amnion cells in premature infants with bronchopulmonary dysplasia: a safety study. Stem Cells Transl Med. 2018; 7(9):628-35.

120. Baker EK, Malhotra A, Lim R, Jacobs SE, Hooper SB, Davis PG, et al. Human amnion cells for the prevention of bronchopulmonary dysplasia: a protocol for a phase I dose escalation study. BMJ Open. 2019;9(2):e026265.

121. Phan TG, Ma H, Lim R, Sobey CG, Wallace EM. Phase 1 trial of amnion cell therapy for ischemic stroke. Front Neurol. 2018;9:198.
122. Ghamari SH, Abbasi-Kangevari M, Tayebi T, Bahrami S, Niknejad H. The bottlenecks in translating placenta-derived amniotic epithelial and mesenchymal stromal cells into the clinic: current discrepancies in marker reports. Front Bioeng Biotechnol. 2020;8:180.

123. Centurione L, Passaretta F, Centurione MA, Munari S, Vertua E, Silini A, et al. Mapping of the human placenta: experimental evidence of amniotic epithelial cell heterogeneity. Cell Transplant. 2018;27(1):12-22.

124. Hou S, Ding C, Shen H, Qian C, Zou Q, Lu J, et al. Vitamin C improves the therapeutic potential of human amniotic epithelial cells in premature ovarian insufficiency disease. Stem Cell Res Ther. 2020;11(1):159.

125. Ferdousi F, Kondo S, Sasaki K, Uchida Y, Ohkohchi N, Zheng YW, et al. Microarray analysis of verbenalin-treated human amniotic epithelial cells reveals therapeutic potential for Alzheimer's Disease. Aging (Albany NY). 2020;12(6):5516-38.

126. Kolanko E, Kopaczka K, Koryciak-Komarska H, Czech E, Szmytkowska P, Gramignoli R, et al. Increased immunomodulatory capacity of human amniotic cells after activation by pro-inflammatory chemokines. Eur J Pharmacol. 2019;859:172545.

127. Wang TG, Xu J, Zhu AH, Lu H, Miao ZN, Zhao P, et al. Human amniotic epithelial cells combined with silk fibroin scaffold in the repair of spinal cord injury. Neural Regen Res. 2016;11(10):1670-7.

128. El Khatib M, Mauro A, Di Mattia M, Wyrwa R, Schweder M, Ancora M, et al. Electrospun PLGA fiber diameter and alignment of tendon biomimetic fleece potentiate tenogenic differentiation and immunomodulatory function of amniotic epithelial stem cells. Cells. 2020;9(5):1207.

\section{Publisher's Note}

Springer Nature remains neutral with regard to jurisdictional claims in published maps and institutional affiliations. 